Florida International University FIU Digital Commons

6-19-2002

\title{
Rethinking the social role of the Catholic Church of Cuba during the Republican period, 1902-1959
}

Leonardo Falcon

Florida International University

DOI: $10.25148 /$ etd.FI15101335

Follow this and additional works at: https://digitalcommons.fiu.edu/etd

Part of the Latin American Studies Commons

\section{Recommended Citation}

Falcon, Leonardo, "Rethinking the social role of the Catholic Church of Cuba during the Republican period, 1902-1959" (2002). FIU Electronic Theses and Dissertations. 3161.

https://digitalcommons.fiu.edu/etd/3161 
FLORIDA INTERNATIONAL UNIVERSITY

Miami, Florida

RETHINKING THE SOCIAL ROLE OF THE CATHOLIC CHURCH OF CUBA DURING THE REPUBLICAN PERIOD, 1902-1959

A thesis submitted in partial fulfillment of the requirements for the degree of

MASTER OF ARTS

in

LATIN AMERICAN AND CARIBBEAN STUDIES

by

Leonardo Falcon 
To: Dean Arthur W. Herriott

College of Arts and Sciences

This thesis, written by Leonardo Falcon, and entitled Rethinking the Social Role of the Catholic Church of Cuba During the Republican Period, 1902-1959, having been approved in respect to style and intellectual content, is referred to you for judgment.

We have read this thesis and recommend that it be approved.

Uva De Aragon

Lisandro O. Perez

Sherry M. Johnson

Carlos M. Alvarez, Major Professor

Date of the Defense: June 19, 2002

The thesis of Leonardo Falcon is approved.

Dean Arthur W. Herriott College of Arts and Sciences

Dean Douglas Wartzok University Graduate School

Florida International University, 2002 
(C) Copyright 2002 by Leonardo Falcon

All rights reserved. 


\section{ACKNOWLEDGMENTS}

I wish to thank my family, friends, and ex-professors who have helped me along this journey. Your love, friendship, and support have been unconditional and I thank you all. I would like to show my appreciation to the Dominican friars, and other religious personalities in Cuba and in Miami for their support with this project. The information provided was crucial and the moral support was invaluable. I want to express my gratitude to the faculty and staff of the Latin American and Caribbean Center and the Cuban Research Institute. Your patience, moral, and economic support for this project have finally paid off. Lastly, I equally thank the members of my thesis committee. Dr. Sherry Johnson: your passion for history inculcated my passion for history. Dr. Lisandro Pérez: your work and comments kept me focused. Dr. Uva de Aragón: your love for the Republic brought about mine; your impetus and observations kept me going. Dr. Carlos Alvarez: your work ethics, patience, understanding, and recommendations brought this thesis to its conclusion.

I will always be grateful to all of you. 


\section{ABSTRACT OF THE THESIS \\ RETHINKING THE SOCIAL ROLE OF THE CATHOLIC CHURCH OF CUBA \\ DURING THE REPUBLICAN PERIOD, 1902-1959}

by

Leonardo Falcon

Florida International University, 2002

Miami, Florida

Professor Carlos M. Alvarez, Major Professor

The purpose of this study was to investigate how the Catholic Church influenced and interacted with Cuban society during the Republic. Specific attention was paid to the question posed by a Cuban scholar if the Catholic Church in Cuba was also the Church of Cuba. The Church's Cubanization efforts were studied through its missionary work, its role as provider of social services, and its capacity to promote sociopolitical changes in the island.

The results showed a Church increasingly working to become a Cuban institution, without losing its catholicity. It was devoted to affecting Cuban society positively through education and healthcare, as well as through its concern for the well-being of the rapidly emerging working class. The interaction of the Church with the workers, and the role of some laypersons and religious personnel culminated in the development of some projects that influenced the Cuban Constitution of 1940. 
I. CHAPTER ONE

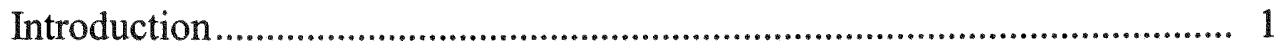

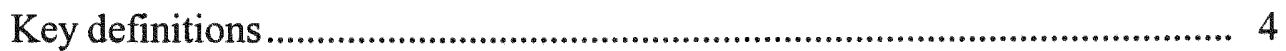

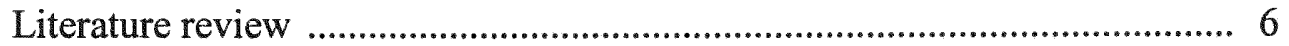

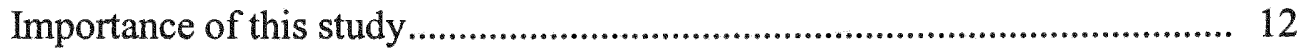

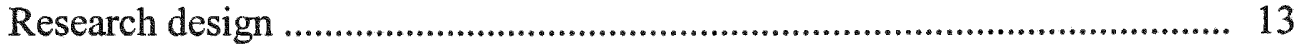

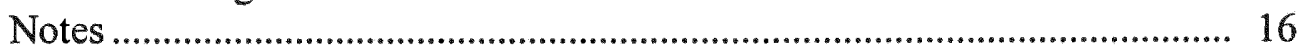

II. CHAPTER TWO

A Church Tied to the Crown: 1492-1898 …................................................ 17

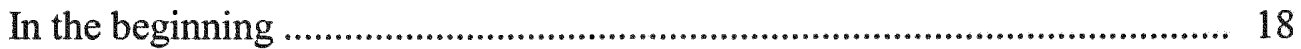

The Church as a promoter of education, first schools .................................. 20

The Seminary San Carlos and San Ambrosio, its origin and development.............................................................................. 21

Real y Pontificia Universidad de San Gerónimo de La Habana ................... 22

Educational reform ................................................................................... 23

Outstanding Cuban intellectuals ............................................................ 27

Decline of the Seminary .................................................................................. 31

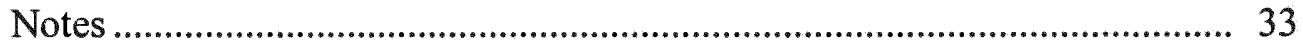

\section{CHAPTER THREE}

A Church in Between, 1898-1902.............................................................. 35

The transition between the colony and the U.S. occupation .......................... 35

The Church under the United States occupation ............................................. 39

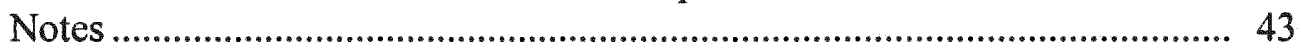

\section{CHAPTER FOUR}

The Catholic Church During the Republic (1902-1959) .............................. 44

The Reorganizational Period (1902-1939) ...................................................... 44

Black nuns for black girls .......................................................................... 52

For the love of God....and for the children ................................................ 53

The Dominican Family, educating at all levels ........................................... 54

Organizing the laity .................................................................................. 56

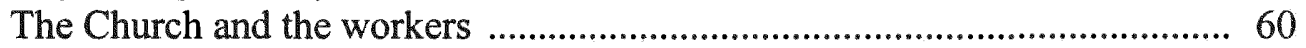

Academia Católica de Ciencias Sociales and the Workers' Legislation........ 62

The Sociopolitical Period (1940-1959)............................................................ 66

Reorganizing the laity into Catholic Action ................................................ 72

The first cardinal ................................................................................. 74

The end of the Republic, and of the splendor of the Church (1962) ............. 79

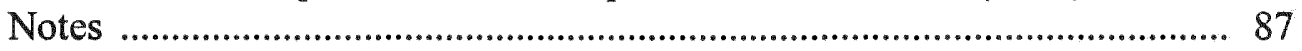


V. CHAPTER FIVE

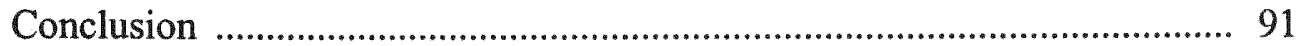

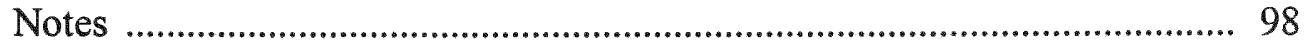

LIST OF REFERENCES _................................................................. 99

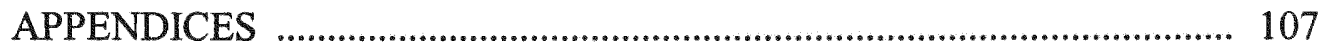




\section{CHAPTER 1}

\section{Introduction}

“... efectivamente no hay placer para un verdadero hijo de la patria, como el de hacerse acreedor a la consideración de sus conciudadanos por sus servicios a la sociedad; mas cuando el bien de esta exige la pérdida de esa aura popular, he aquí el sacrificio más noble y mas digno..." (Varela 1992, 153).

The history of the Catholic Church in Cuba is intricately and intrinsically related to the history of Cuba since 1492. The arrival of the first Spanish settlers in Cuba marked the beginning of the evangelization of the island. Very early during the colonization period, the Catholic Church in Cuba played an active role as provider of social services. Its religious orders and congregations were responsible for founding the first hospitals, orphanages, and hospices in the island. The Church also established the first schools, academies, and universities.

While the health-related institutions created by the Catholic Church assisted the population with vital means for survival, the educational institutions contributed to the emergence of a Creole intellectual class. Gradually, those educated at the Catholic Church's institutions played a pivotal role in the development of the Cuban national identity. They were also partially responsible for the sociopolitical reforms that led to the eventual independence of the island from Spanish domination.

The legislation that regulated colonial Cuba did not establish a division between religious and civil authorities. Those regulations allowed for overlap. Moreover, they gave the Spanish government the power to appoint the religious authorities for the island, and to legally control the Catholic Church's social role and political stances. At the same time, the colonial government contributed economically towards the Catholic Church's 
endeavors. The end of the Spanish dominion over Cuba in 1898 put an end to both the control and the subvention of the Catholic Church by the crown.

The advent of a republican form of government, constitutionally regulated, called for the reorganization of Cuban social, economic, religious, and political institutions. The new order, among other dispositions, established the separation of Church and State, and that the government would not finance any religious activities. The Church, as any other institution in the island, was prompted to redesign itself in order to adapt to the newly-established conditions. It needed to develop a series of strategies for its reorganization in order to effectively ensure its continuity.

The Catholic Church had to rethink specifically its position and role as provider of social services. Its new situation represented an opportunity to prove its institutional maturity by competitively organizing itself as a Cuban institution. In other words, the Catholic Church in Cuba was called to Cubanize itself. This meant that the Catholic Church had to demonstrate its degree of sociopolitical adulthood through its capacity to integrate within its plan of actions efficient strategies to satisfy the needs of its Cuban constituency.

The Catholic Church in Cuba (henceforth referred to, interchangeably, as the "Church") was challenged by its new reality to become a Church "rooted in the struggle of human beings to make a nationality and to use their religious feelings as solace, as motivation, as means for survival, as a way to relate to transcendence, as a strategy to link the past to the present and to the future" (Dominguez 1989, 44).

This thesis offers a revisionist sociohistorical overview of the social role of the Catholic Church in Cuba during the first half of the twentieth century. It emerged, 
among other reasons, from a question posed and left unanswered by Dominguez (1989, 44): was the Catholic Church in Cuba also the Church of Cuba?

Dominguez classified the Church as the Church of Spain during the colonial period (1492-1898) ${ }^{1}$, and, in more recent times (post 1959), as the Church of Miami, or at least the Church in Cuba of those who would rather be in Miami (Dominguez 1989, 44). Although Dominguez addressed the role of the Church during the Republic, he did not clearly assign a "national" affiliation for the Church during that time.

This study will attempt to answer the question by analyzing information which will support the thesis that the Catholic Church in Cuba was also the Church of Cuba during the Republic. The focus is on the role the Church played and what it accomplished during the Republic. The main factors to analyze are: its missionary work; its role as provider of social services, i.e. education and healthcare; and its role as a promoter of sociopolitical changes. They are analyzed as the mechanisms through which the Church strove towards its Cubanization. ${ }^{2}$

The Cubanization of the Catholic Church serving Cuba during the Republic is seen as an evolutionary process measured by three interrelated factors: 1) the gradual increase in the awareness of religious personnel of their role in Cuban society; 2) the hierarchical alliance among the bishops, religious personnel, and laity and the results of that alliance; and 3) the level of credibility that the religious personnel achieved within the constituency. These three concepts will be further addressed in the conclusion, following the historical analysis. 


\section{Key definitions}

Most definitions used for this thesis borrow from the work of Abelardo Jorge Soneira: Las Estrategias Institucionales de la Iglesia Católica en la Argentina (18801976). Although the Church in Cuba and in Argentina have very different histories and consequently played different roles in their particular societies, they are connected through the catholicity (universality) of the Church. Therefore, the definitions used in Soneira's work apply to the Church in Cuba as an international institution serving a particular nation.

The term Catholic Church refers to an organized structure oriented towards the satisfaction of human needs of religious nature. The Catholic Church is a hierarchical institution whose ultimate function is the salvation of the soul of those men and women with whom the Church interacts. It has the duty of disseminating its doctrine through the evangelization of the people. The Church, however, over the years has acquired the secondary function of contributing towards the satisfaction of basic human needs, such as the education and healthcare of those it evangelizes. The latter is a tangible function through which the Church is evaluated and its role within society is measured.

For the purpose of this thesis the term Church refers to all the members and organizations of the Catholic Church, classified, in hierarchical order, as: archbishops, bishops, religious personnel [which includes bishops, priests, members of religious orders and congregations (friars), and nuns], clergy [does not refer to the nuns but includes those mentioned as religious personnel], and laity. Wherever a statement applies only to a particular group or individual, it will be specified. It is of extreme importance to denote 
that, the term "Church" does not refer solely to the hierarchy, so as to avoid the historical mistake of judging the Church through the hierarchy's role or stance.

Archbishops and bishops are priests in charge of the direction of a particular archdiocese or diocese. Unless a distinction is made between the two, the term "bishops" includes both categories. The term priest (Fr.) refers to an ordained minister of the Church. Whenever a person belongs to a religious order or congregation (Jesuits, Dominicans, Franciscans, etc), or if he is a brother, it will be specified.

The term charisma, when applied to a religious order or congregation, is used to denote the specialization, or secondary function, mandated in the particular constitution governing that religious order or congregation. For instance, the charisma of a Dominican friar is studying and preaching, the charisma of an Oblate of the Divine Providence is the education of black children.

For the purpose of this thesis the "Cubanization of the Catholic Church" refers to the following specific stances and actions of "the Church" (as defined in this study). First, the growth in number of religious personnel that identified with the causes and needs of the Cuban nation. Second, the Church's acknowledgment and work contributing to alleviate the needs of the population. Third, the promotion of native clergy to hierarchical positions. Fourth, the identification of foreign personnel with the Cuban causes and their acceptance by the native personnel and laity. Fifth, the identification of religious symbols and ceremonies with Cuban nationalism. Sixth and final, the efforts of the Church for becoming a Church ingrained within Cuban society.

The "Cubanization of the Church" does not imply that the Catholic Church was the only Church in the island, nor that it was accepted by every Cuban. It does not refer 
to a national ownership of the Church's properties by the population, nor to the establishment of a national Church separated from Rome.

\section{Literature review}

The research and interviews conducted for this work revealed that the literature available analyzing the social role of the Catholic Church in Cuba in general is scarce. The paucity of literature is also affected by the focus of this thesis, that is, the Cubanization of the Church. The abovementioned article of Jorge Dominguez is virtually the only source in this area.

Not only is the literature on the subject scarce, but also contradictory. For instance, some authors have defined the Catholic Church in Cuba as a weak institution at some specific moments (Pérez 1994, 148; Crahan 1989, 3). The authors' conclusions point to the perceived role of the Church during the independence wars of the nineteenth century and the official stances of the hierarchy and some clergy in favor of the Spanish government. Paradoxically, in the same article Crahan describes the Church as a strong organization, with specific influence in such crucial sectors as education and welfare (Crahan 1989, 4). For others, Catholic religious symbols, such as La Virgen de la Caridad, are intrinsically related to Cuban nationality (Díaz 2000,43), which implies a great degree of influence of Catholicism in people's lives. Even others have written about the historical moments in which Cubans have celebrated acts of national relevance, such as the independence of Cuba from Spain, with Catholic religious ceremonies (Larrúa Guedes 1996, 181).

The available literature is also limited by the time period chosen for this thesis. While the literature about the Church during the colonial period and during Castro's 
government is relatively abundant, there is not a specific book written on the social role of the Church during the Republic nor on the Cubanization of the Catholic Church. As such, the Cubanization of the Church during the Republic has no literary precedent upon which to rely. The history of the Church during the Republic, is briefly analyzed in articles and sections of books, mostly as means to arrive at the immediate events that led to Castro's revolution, mentioning the role of the Church during and after.

This thesis emphasizes the study of the social role of the Catholic Church in Cuba not conditioned by the events of 1959 . Instead, the events of 1959 are interpreted as the unexpected interruption to the evolutionary process of the Cubanization of the Church. In other words, this thesis analyzes the role of the Church during the Republic only as a response to the social needs of that period as to avoid erroneous conclusions based solely on the events that immediately preceded and followed the Revolution of 1959 . Those events, though mentioned in this work, do not accurately represent the strengths or weaknesses in the role of the Church during the whole republican period.

Taking the above statements into account, the issue of the strength of the Church in Cuba has been divided here into two schools of thought. The first one classifies the Church as a strong and influential institution and is represented by three main authors: Ismael Testé, Juan Martín Leisca, and Teresa Fernández Soneira. The works of these authors are of extreme importance as they offer detailed historical data. They, however, lack the analytical approach found on those in the second group.

The second group classifies the role of the Church as generally weak. The term "generally" points to the fact that for these authors the Church was influential in some instances or aspects of society but weak in others. Within this group the authors that 
have influenced this thesis the most are Manuel Fernández Santalices, Margaret Crahan, and Jesús Belda Mas. The works of other authors are used in this study as complementary to the analysis.

Because this thesis attempts to go beyond the scope of currently available literature it is largely based on primary sources. Those sources include, among several others, the Boletín Oficial de la Provincia Eclesiástica de la República de Cuba, the pastoral letters of the bishops published in the book La Voz de la Iglesia, cien documentos episcopales, and the Revista Antillana. The benefit of using primary sources allows this thesis to arrive at an independent and revisionist conclusion.

The Historia Eclesiástica de Cuba, written by Ismael Testé in five volumes is the most extensive work on the history of the Church in Cuba up to the Revolution of 1959 (Testé 1969; Testé 1970; Testé 1973; Testé 1974; Testé 1975). His work is mainly used in this thesis to obtain biographical data and historical information on the persons and organizations that intervened in Cuban history. Although Testé classifies the role of the Church as an influential institution, this thesis agrees with Testé's view only to a certain extent.

While it is true that the Church played an important role in the education and healthcare of the population, this was not evident at all levels during the whole republican period. For instance, the presence of religious personnel in the urban and rural areas was not proportional. Religious personnel in the rural areas was historically underrepresented. In addition, the role of the Church in the political life of Cuba was not a constant fact. Although both issues gradually improved between 1902 and 1959, they were not a constant as Testé implies (Testé 1975). This thesis avoids relying on Testé's 
opinion towards the end of the Republic as his analysis is deeply influenced by the effects that Castro's revolution had on the Church and on him.

Testé relies upon original documents, included in volume five, and on the investigations of Juan Martín Leiseca. Leiseca's book, Apuntes para la Historia Eclesiástica de Cuba, was written in 1938. Hence, it is used in this study for the end of the colonial period and the beginning of the Republic. This thesis also used Leiseca's work mainly to obtain biographical and historical data, although some of his conclusions are taken into consideration.

A third work, used to obtain primarily historical data, is Cuba, Historia de la Educación Católica, 1582-1961, by Teresa Fernández Soneira. Her work is a compilation of the historical accounts about the foundation of educational institutions in Cuba up to the nationalization laws of Castro's government in 1961-1962. The two volumes written are important for this thesis as it offers a detailed account of the efforts of different religious orders and congregations in providing education in Cuba. The books include copies of original documents, letters by alumni of the different schools, and quantitative data that are used in this thesis to evaluate the role of the Church in the education sector.

Soneira's work is influenced by Testé's books, and by the works of her uncle, Manuel Fernández Santalices. Fernández Santalices (1998) analyzes the role that different religious personalities and Catholic organizations played during the twentieth century. His opinion with regards to the social role of the Church in Cuba during the Republic is the closest to the one offered in this thesis. For him, the Church responded to the sociopolitical needs of its time, centered on, and emerging from, its primary role of 
saving souls (Fernández Santalices 1998, X). The services offered by the Church, such as education and healthcare, although of extreme importance, are a secondary function of the Church. His book analyzes the active role of the laity in Cuba as a part of the Catholic Church, and not as a separate entity, acting on its own. As such, he reinforces the idea expressed in this thesis, that the role of the Church is tangible and measurable through the role of all its component parts alike, and not just through the role of the hierarchy, an individual, or a particular organization.

Misjudging the Church based on the actions or ideals of a particular group or person is a major flaw in the work of other authors such as Margaret Crahan (1989). For instance, based on the stances of the Archbishop of Santiago de Cuba Enrique Pérez Serantes and the Agrupación Católica Universitaria (ACU) during the late 1950s, Crahan classifies their individual roles as positive. At the same time, she refers to the role of "the Church" as weak (Crahan 1989, 5). This notion is rather confusing only because the author fails to recognize that Pérez Serantes and ACU acted as members of the Church. In addition, Crahan does not take into account that $\mathrm{ACU}$, a group part of the Cuban laity, had a rather large membership.

The third work within this group is that of Jesús Belda Mas, Cuba, ¿a dónde vas? Belda's contribution to this thesis is his analysis of the Church during the Republic as a pre Second Vatican Council institution. He clarifies that not until that council and the subsequent Latin American meetings at Puebla and Medellin in the 1970s, was the position of the Church officially defined with respect to political interference and the "option for the poor" (Belda Mas 1999, 89-91; 98-101). As such, the Church in the 
Republic cannot be judged from a post Vatican II perspective, which allows for the integration of the Church in the political life of the particular country it serves.

Relying on Belda's stance on the division between the political and social roles of the Church pre Vatican II, this thesis examines the history of the Church during the Republic as an institution concerned with social and not with political affairs. The instances in which the Church intervened in the political life of the country are an indirect result of its preoccupation for social matters. As Belda Mas states in his work, only from that perspective "podemos comprender lo que la Iglesia hizo, e incluso podemos quizás admitir que no pudieron hacer otra cosa, dados sus condicionamientos y su mentalidad histórica" (Belda Mas 1999, 102).

There is a particular work that should be mentioned here as it, indirectly, influenced this thesis by clarifying the role of corporatism and "lo informal" in Cuba. The work is Cuba and the Politics of Passion, by Damián Fernández. This book contributed to the understanding of how the corporatism of the Church could be integrated with the Cuban idiosyncrasy in order to achieve the Cubanization effect.

As an international organization, the Church is a corporatist institution, which in Cuba was encouraged by centuries of Spanish colonialism. The corporatist paradigm endorsed the notion of law, order, stability, and elite leadership through a centralized bureaucratic authority -the bishops- that would rule over and in coordination with, sectoral groups hierarchically and organically integrated (Fernández 2000, 27).

As an institution striving towards its Cubanization, the interaction between religious personnel and laity was highly based on "lo informal". As Damián Fernández wrote, Cubans "value the personal touch, the role of person-to-person contact, and the 
bond of affection above the impersonal norms of the state in order to deal with, if not circumventing the demands of the regime to satisfy the material and nonmaterial needs of the community" (Fernández 2000, 29).

The Catholic Church in Cuba must be analyzed in the Republic through a combination of both assumptions, as a corporatist and as an institution marked by $l o$ informal, due to the convergence of two realities. The Church in Cuba was part of a transnational, corporatist institution, obeying its head in Rome, while at the same time it was locally headed and integrated mostly by Cubans. This convergence of realities was a strong underlying factor for the Church's success in its Cubanization without attempting a break from Rome.

\section{Importance of this study}

The importance of this thesis rests on its revisionist approach. It illustrates the efforts of the Catholic Church to affect positively Cuban society during the Republic. Moreover, in attempting to affect the current scholarly opinion, which generally classifies the Church as uninfluential, it offers information on how the Church contributed, through education, to the socioeconomic betterment of Cuban individuals resulting in the overall improvement of the nation. It also points out the efforts of those overlooked or misjudged Catholic individuals and organizations, an important part of the nation, which played a significant role in Cuban society during the Republic.

While the preoccupation of the Church for the workers has been mentioned in several studies, the influence that some projects developed by members of the Church might have in the 1940 Constitution had not been pointed out, or at least encountered in the literature on the subject. The emphasis of this work on the relationship between the 
Church and the working class, establishes a connection between two important groups in Cuban society that, until now, has not been sufficiently studied.

In addition to the role of the Church with the working class, this thesis illustrates the efforts of the Church throughout the Republic to contribute to the education of the masses. Inasmuch as it accomplishes these two points, this work contributes to the clarification of the popular misconception, reinforced by some scholars, that the Church in Cuba was only the Church of the rich. While it is true that the Church received considerable support from the upper classes, this does not necessarily mean that the interests of the Church lay exclusively within that sector of Cuban society.

This work tries to demystify the idea that the Catholic Church was an anti-Cuban institution. The approach taken in this study in demonstrating the Cubanization of the Catholic Church through its role as provider of social services, reincorporates the Church into Cuban reality. In doing so, this thesis hopes to be the first of many revisionist studies that will reinterpret the role of the Church in Cuba and its accomplishments during the Republican period.

\section{Research design}

This thesis investigates the Catholic Church in Cuba in its role as a provider of social services during the Republic. It shows the efforts of the Church to contribute actively in the social welfare under the new republican government by continuing to provide many traditionally established services. The unit of analysis of this study is the Catholic Church as an international institution attempting to become a Church rooted in Cuban society. This thesis also aims to show the processes through which the Church 
became a Cubanized institution, regardless of the foreign nationality of several of its members, and the Church's dependence from Rome.

This study places and emphasis on the rapid growth of the Church, its organizational capacity, and its accomplishments during the Republic regardless of the challenges it faced. Some of those challenges were the competition with other religious groups, the anticlericalism of the time, and the lack of religiosity of some sectors of the Cuban population (Dominguez 1989, 43-46).

The theoretical framework for this thesis borrows from the socio-anthropological theory of functionalism, developed by Bronislaw Malinowski and A. R. Radcliff-Brown. Functionalism attempts to describe the various institutions that make up society, explain what they do, and show their contribution to the overall maintenance of society (McGee and Warms 1996,158). This approach focuses on how social structures maintain, or strive to maintain, the equilibrium of society. It places more importance on the overall contribution of an institution throughout time, than on individuals at a particular moment in history, although it takes into account the role of individuals within the established structures, as they modify those structures (McGee and Warms, 157-160).

Chapter two of this study offers a historical overview of the Catholic Church during colonial times, 1492-1898. Its purpose is to establish a historical background as well as the continuity in the proactive role of the Church in Cuba. The emphasis is put on the seminary San Carlos and San Ambrosio, as it was a visible venue through which the Church influenced the development of the Cuban national identity. This chapter also offers a biographical overview of some men whose ideas and actions influenced Cuba socially and politically. 
Chapter three describes the short period during which Cuba was occupied by a provisional government from the United States. This period is important as it shows how the Church, immediately after being freed from Spanish control, struggled to voice its rights. It shows also the first steps of the Church for becoming Cuban. This is the time in which the Church began to rethink its future role within Cuban society.

Chapter four focuses on the main argument of this thesis, which is the gradually increasing efforts of the Catholic Church to become Cuban and its accomplishment during the Republic. The chapter is divided into two periods. The Reorganizational Period, 1902-1939, and the Sociopolitical Period 1940-1959. This division has been established in this thesis to emphasize the different processes in which the Church was involved.

The chapter focuses on the role of different organizations and personalities in the development of a Church aware of the needs of society, and actively involved in the search for permanent solutions to those needs. It also describes the gradual growth of the Church both in laity and in religious personnel as well as their involvement with the rapidly increasing working class, and the projects that emerged for their benefit. Those projects are later shown to have affected the provisions in the Constitution of 1940.

The chapter ends with an overview of the international recognition of the Church with the election of a cardinal, a short revisionist biography of the Cardinal, and the chaos related to the events of 1959. This chapter illustrates that the Church was indeed trying to contribute to the peaceful solution of the conflict that culminated with Castro's arrival to power. The chapter is extended to 1962 only to show the forced demise of the Church. 
Chapter five offers the conclusion of the thesis and reviews the main goals posed at the beginning of this study and how they were accomplished by the Church. The chapter goes over the points that contributed to the gradual Cubanization of the Church and reviews and analyze the factors introduced.

\section{Notes}

${ }^{1}$ Dominguez assertion that the Church in Cuba during the colonial period was the Church of Spain is partially accurate. It was a Church legally tied to the crown, but that was officially, because, as illustrated in Chapter 2 of this thesis, unofficially the Church's stances did not always match those of Spain. The current period, post 1959, is not addressed in this thesis as it goes beyond the scope of this work.

${ }^{2}$ This notion, as well as subsequent phrases such as "on becoming Cuban", borrow from the title of the book written by Louis A. Pérez Jr., On Becoming Cuban. Identity, Nationality, and Culture. Chapel Hill, NC: University of North Carolina Press, 1999. 


\section{CHAPTER 2}

\section{A Church Tied to the Crown: 1492-1898}

This chapter reviews the history of the Catholic Church in Cuba during the colonial period (1492-1898). Although the focus of this thesis is the Republic, an overview of the Church in colonial Cuba is essential to understand the role of religious personnel, organizations, and lay persons in the development of the Cuban national identity. It is also crucial to comprehend the social stances of the Catholic Church during the Republic.

The emphasis of this chapter will be on the history of the Seminary San Carlos and San Ambrosio, although the University of La Habana is briefly discussed. These educational institutions constitute the greatest examples of the historical efforts of the Catholic Church to positively affect Cuban society. They were the intellectual/religious settings from where so many important Cuban figures emerged in the $19^{\text {th }}$ century.

Although not studied in this chapter, it is worth mentioning that the Catholic Church in Cuba also played an important role in other social sectors of Cuban society such as caring for the sick. The Church founded numerous hospitals, hospices, and orphanages throughout the island and provided the personnel and finances to maintain them, contributing to the well being of the population (Testé 1975, 93-101).

This chapter will illustrate that the Catholic Church, regardless of the restrictions and control imposed by the Spanish crown, was not always supportive of Spanish intentions. It also reveals that the social stance of the Catholic Church during the Republic was a continuation of the tradition of the Church as a social agent during most of the nineteenth century. 


\section{In the beginning...}

The creation on February 15, 1516, of the Diocese of Nuestra Señora de la Asunción de Baracoa ${ }^{I}$, and the election of the Dominican Friar, Bernardo de Mesa (Meier et al. 1995, 59) as its bishop, marked the canonical commencement of the history of the Catholic Church in Cuba ${ }^{2}$. Unofficially, however, the Catholic presence on the island began in 1492 with the arrival of the first Spaniards and their religious companions (Larrúa Guedes 1996, 3).

During the first few years after the Spaniards first appearance in Cuba, the island was relatively unimportant. It was not until 1511 that the Spanish colonization and the efforts for the evangelization of the island's inhabitants began. Consequently, religious personnel were not permanently established in Cuba until that year. They had been given the mission of accompanying the new settlers as their spiritual guide as well as converting the natives to the Catholic faith.

Their mission had been decreed a few years earlier, in 1508, by Pope Julius II, in the bull Universalis Ecclesie. The bull established what became known as Patronato Regio or Real Patronato. According to this document "el Estado Español se constituia en Administrador de las rentas y medios de vida de la Iglesia en América" (Testé 1969, 22). In other words, the Pope not only gave the Spanish crown the right to oversee the evangelization of the New World, but also the right to appoint the bishops and to control the actions of the Catholic Church in the colonies. From that moment until the end of the colonial period, the cross and the sword, under the Spanish crown, interacted on the Caribbean island to govern, but also to influence the formation of its national character. 
For centuries the Patronato Regio turned the Catholic hierarchy in the colonies, at least officially, into subordinates not of the Popes and their religious policies, but of the Spanish monarchs and their political plans. The clergy in Cuba, however, did not take submission to the crown very seriously. They, as the majority of the Cuban population, constantly circumvented the crown's mandates in order to satisfy their needs (Fernández 2000, 29).

Soon after the foundation of the first villas in Cuba the Spaniards began the enslavement and exploitation of the island natives in search of gold. This exploitation, among other causes such as diseases and suicide, lead to the eventual decimation of the natives. A Spanish man, Bartolomé De Las Casas, later a priest member of the Order of Preachers (Dominicans hereafter) and a slave owner, arrived on the island with the first permanent settlers. Before long, he realized that the enslavement of the natives was a blatant transgression of the Christian doctrines of the Church. Las Casas freed his indigenous slaves, raised his voice against the mistreatment of the natives, and became their protector. Supported by his Dominican religious brothers from La Española, he was the foremost advocate of the rights of the autochthonous inhabitants of Cuba, and subsequently of the Americas (Larrua Guedes 1996, 9-12).

The approval of the Real Ordenanzas of $1542^{3}$ (Larrúa Guedes 1996, 9-12), proposed and adamantly defended by Las Casas in Spain, became the first example of the proactive role of the Catholic Church in Cuba. The ordinances protected the natives from enslavement by the Spaniards, declaring that the natives were as human as the Spaniards and as such, deserved equal rights and treatment. Although the colonizers did not fully abide by the Ordinances, Las Casas had won legal protection for the natives. His victory 
was also the first victory of the Church in defense of the disadvantaged, not only on the island but also in the rest of the new Spanish possessions. Las Casas was the first in a series of religious personalities who stood behind noble causes needing advocacy in Cuba.

The sixteenth and seventeenth centuries constituted a period of a slow gestation of the Cuban colonial society. The lack of precious metals on the island and the conquest of Mexico and Peru provoked the exodus of the majority of the colonizers and religious personnel, leaving Cuba practically unpopulated. As a result, the Catholic Church in Cuba grew at a slower rate when compared to the Church in the mainland colonies (Segreo Ricardo 2000, 11).

In 1561, bishop Bernardino de Villalpando wrote to king Felipe II "En esta isla, con ser tan grande, no hallé sino 5 clérigos: 2 en esta villa (La Habana) y 2 en Bayamo y 1 en Santiago. Otros tres pueblos hay en la isla, que son Zavana y Santo Espiritus y Puerto Príncipe, que ninguno de ellos tiene sacerdotes, ni hay quien quiera vivir en ellos" (Marrero 1972, 2:324).

\section{The Church as a promoter of education, first schools}

In 1522 a Bull by Pope Adriano VI established La Scholatria, the first educational institution on the island. The school was located next to a church in Santiago de Cuba (Testé 1975, 79). At this school children were taught, at no cost, Castilian and Latin Grammar. By 1544 the school was under the direction of Fr. Miguel Velázquez, nephew of the conquistador Diego Velázquez. He was the first Cuba-born teacher and priest (Fernández Soneira 1997, 1:13). 
At the other end of Cuba, a group of Jesuits established themselves in La Habana in 1569 founding the first educational institution in the city. The school, however, had to close its doors in 1574, when the Jesuits were transferred to Mexico. Other religious orders such as the Dominicans, the Augustinians, the Franciscans, and the Clarissines, opened several schools in the city. Thus, children arriving to or born in the flourishing city of Havana could be educated (Segreo Ricardo 2000, 17).

As the young population increased and the children grew, and in the absence of education provided by the government, the Church was faced with the task of providing higher education. At the same time many of the young men discovered their religious calling, becoming the first local vocations. These men who wanted to become priests needed adequate intellectual and religious formation. The foundation of a seminary to educate the future Cuban priests became a priority (Segreo Ricardo 2000, 17). ${ }^{4}$

\section{The Seminary San Carlos and San Ambrosio, its origin and development}

With the arrival of bishop Diego Evelino de Compostela, in 1685, those working for the establishment of an institution of higher education found not only an enthusiastic ally, but also economic support. The bishop contributed with 10,000 duros. ${ }^{5}$ He also purchased the land known as La Placita de la Ciénaga, on which later were built the seminary and the cathedral of La Habana (Buch Sánchez 1999, 74).

In 1689, Compostela received the necessary permits from the Spanish crown to open the school, which he named Seminario San Ambrosio. The seminary was formally inaugurated on June 9,1692 . The boys attending the new school were taught grammar, civics, Latin, and music, and once they had reached a proper age, the bishop hoped, they would continue into the priesthood. He also founded a school for girls, Colegio de San 
Francisco de Sales. Both schools were free of charge, since they were financed by the bishop's personal fortune (Testé 1975, 51-53).

After the death of bishop Compostela in 1704, his successor, Jerónimo Valdés y Sierra, known for the foundation of several social and educational institutions throughout the island ${ }^{6}$, gave the responsibility for the direction of Colegio de San Ambrosio to the Jesuits. A few years later, a Cuban priest, Gregorio Díaz, donated his fortune of 40, 000 duros for the remodeling and maintenance of this educational institution (Testé 1975, 5153). The following years witnessed few noticeable advances for the institution. Several bishops that took over the direction of the Church did not envision the development of a multidisciplinary curriculum for the seminary.

\section{Real y Pontificia Universidad de San Gerónimo de La Habana}

“...el 5 de enero de 1728, en uso de las facultades que le confería el Breve apostólico de 12 de septiembre de 1721, (el prior de los dominicos) dictó auto fundando por si mismo, en privado y en la intimidad del convento, la Universidad de La Habana..." (Larrúa Guedes 1997, 119).

The Dominicans' concern for quality education was part of their charisma. Thus, the friars working in Cuba sought the establishment of a university to satisfy the need for higher education on the island. In order to offer the best possible instruction, the Dominicans tried to bring friars schooled in the most contemporary and liberal theoretical approaches to their faculty. Throughout the years, those who attended the university were taught in the sciences the theories of Nicholas Copernicus, Galileo Galilee, Leonardo da Vinci, and Isaac Newton. In Philosophy and Theology they learned from René Descartes, Blaise Pascal, and of course, St. Thomas Aquinas. There were four Major Schools or Facultades Mayores at this institution: Medicine, Law, Theology, and 
Canon Law. There was one Facultad Menor, of Arts and Philosophy (Larrúa Guedes 1997, 119-144; Larrúa Guedes 1998, 178-236).

The University of La Habana was the only educational institution permitted to confer higher degrees on the island as per royal ordinances. Consequently, those who studied at the Seminary were required to take some classes at the university. They also had to take competitive exams at the university from where they officially obtained their degrees. For this reason those who studied at the seminary appear in historical documents as graduates of the University of La Habana.

\section{Educational reform}

On July 11,1767 , the Jesuits, who until then had directed the seminary, were expelled from the island. Although some consider their expulsion as beneficial for the Cuban economy ${ }^{7}$, their departure had serious consequences for the seminary and for education in general. They had been in charge of the seminary since its foundation and were in charge of several other schools at the time (Buch Sánchez 1999, 77).

Upon the departure of the Jesuits, bishop José de Hechevarría, the first Cubanborn bishop, took over the school, and recognizing the need for better higher secular and ecclesiastic education, reformed the institution. He established the Real Colegio de San Carlos y San Ambrosio, on March 3, 1769. Pragmatically, the bishop did not establish a seminary, but a Real Colegio; thus it could be attended by both laymen and aspirants to the priesthood (Buch Sánchez 1999, 86-88). Until then they had been educated at separate institutions, hindering the interaction between the religious and secular Cuban intelligentsia. It was a very innovative concept for a promising institution. 
Students who until then had access only to the University of La Habana, now also could pursue higher education at San Carlos y San Ambrosio. Conversely, candidates to the priesthood who were limited only to ecclesiastic instruction, found themselves exposed to liberal ideas coming from the university. The combination would prove very fruitful, and soon the halls and classrooms of the Real Colegio de San Carlos y San Ambrosio, would become the setting for the maturation of the most progressive Cuban thinkers of the time.

Bishop Hechaverria wrote the constitution for the Real Colegio. In the preamble he left clear his intentions of reforming the institution in order to form an authentic intellectual class on the island. He wanted to promote competent thinkers, men capable of dignifying the Church, the state, and the people (Buch Sánchez 1999, 79). At the same time, and in accordance with the mentality of the time, race and social class limited access to such an institution. The constitution forbade the acceptance of Jews, Moors, new converts, blacks, mulattoes, and mestizos (Fernández Soneira 1997, 108).

The rules, however, were not always followed, and in an effort to promote those from the lower orders, the Church helped them economically. A large number of young men that attended the seminary were from the lower social strata. There were twentyfour scholarships established for those who could not afford a quality education and attended the seminary (Buch Sánchez 1999, 76-80).

The professors were selected through arduous competitive examinations, and the constitutions of the seminary were extremely clear about the role and qualifications of the professors. Hechaverría wanted knowledgeable and highly regarded professors to generate competent and reputable graduates (Buch Sánchez 1999, 81-83). 
Another innovative aspect of the Real Colegio, which also "circumvented" the rules, was that both clergy and laypersons were incorporated into the faculty. The laymen were slowly introducing the liberal teachings of the Enlightenment coming from European institutions. They were in charge of assisting the future priests in finding rational explanations to all existential, human, and divine things (Leal 1997, 90).

The seminary, however, would not see the fruits of its innovative curriculum for a few more years. The enlightened Hechaverría was named bishop of Puebla in Mexico, and was succeeded by bishop Trespalacios, a man who did not see education as important. He believed that education could provoke unrest in a world already plagued by revolutions (Leal 1997, 94).

The dark age of Trespalacios was followed by the arrival in 1800 of a progressive bishop, Juan José Díaz de Espada y Landa, who took over the diocese of La Habana and of the seminary in 1802 . With his arrival "La Habana gained a prelate that was to transform public sanitation, to raise higher studies, combat popular ignorance, look after the arts, modify our customs, and, during the third of the century, to turn the corrupt colonial environment into a society capable of triumphing over its own miseries" (García Pons 1951, 42)

Although Espada was Spanish by birth he was Cuban by his actions. His antislavery ideas and his confidence that quality education was a transforming social power became the basis for the progressive reforms he introduced to the island. His arrival would give the educational and nationalistic activities of the seminary a new and definitive impulse. The seminary became the intellectual platform from where the bishop's reforms were launched. Espada focused his energy and utilized his personal 
fortune to turn the seminary into a center of vast knowledge, great reputation, and unconditional love for the Caribbean island he served (Segreo Ricardo 2000, 83-115).

He searched for and found qualified men, such as the seminary professor Fr. José Agustín Caballero, to teach at San Carlos and San Ambrosio. He wanted men capable, through their knowledge and love for the art of teaching and for Cuba, of elevating the excellence of the seminary as well as promoting the betterment of society. The bishop also needed men capable of attracting a large number of disciples (Segreo Ricardo 2000, 83-115).

One of Espada's first reforming measures was to expand the seminary curriculum. In 1807, the departments of Civil Law and Mathematics were created. In 1817, labs for physics and chemistry were opened, and for the first time in the history of Cuba classes on these subjects were taught. In 1818, the department of Economics was added ${ }^{8}$ (Buch Sánchez 1999, 87-88).

\section{Outstanding Cuban intellectuals}

All of these reforms attracted a large number of men, 700 by 1821 (Buch Sánchez $1999,88)$. Many of them would be key in the formation of the Cuban national identity. They became some of the most prestigious Cuban philosophers, priests, economists, lawyers, publicists, doctors, historians, professors, and poets of nineteenth century Cuba (Buch Sánchez 1999, 72).

Among the many prominent figures who taught and/or attended San Carlos, were José Agustín Caballero, Felix Varela, José de la Luz y Caballero, Rafael Maria De Mendive, José Antonio Saco, Francisco de Arango y Parreño, Domingo del Monte, Cirilo 
Villaverde, Gaspar Betancourt Cisneros, José Maria Heredia, Carlos Manuel De Céspedes, and Tomás Romay (Buch Sánchez 1999, 72).

Felix Varela y Morales (1788-1853) followed his vocation to become a priest and entered the seminary under the tutelage of the memorable Cuban priest José Agustin Caballero about whom Msgr. Llaguno in his Brief History of the Seminary said:

"A más de sus trofeos tan gallardamente conquistados en el dificil campo de la oratoria y de sus monumentales trabajos en la cátedra del Seminario, le cabe la gloria inigualada de haber formado en sus aulas la inteligencia extraordinaria del hombre que nos enseñó a pensar: el inmortal y virtuoso Padre Varela..." (Buch Sánchez 1999, 88).

It was Fr. Varela, urged by bishop Espada, who inaugurated and accepted the position of Dean of the School of Constitutional Law at the seminary. This school became the first one of its kind in the new world, and under the Spanish crown. At this school, Varela analyzed and taught the Constitution of 1812, and the subsequent reforms of 1822 and 1823, a reformist process in which he had also participated. It was also the same bishop Espada who later convinced Varela to represent Cuba at the Spanish courts. Varela was to defend the need for the autonomy of the island and the abolition of slavery. Neither the bishop nor Varela suspected that the trip would become Varela's definitive exile (Leal 1997, 95-96; Céspedes García-Menocal 1998, 120-132).

Varela has been recognized as a father of the national culture, an educational reformer, and "el primero que nos enseñó a pensar y a pensar como cubanos" (ENEC 1987, 36-37). The same source indicates that Varela was the first one to proclaim the need for the total liberation of Cuba from the Spanish metropolis. He made public his conviction, in reference to Cuba, that only a profound moral transformation at the 
personal level could make possible the salvation of the individual and society: "No hay Patria sin virtud, ni virtud con impiedad" (ENEC 1987, 36-37).

Another illustrious Cuban, José de la Luz y Caballero (1800-1862), entered the seminary in order to become a priest following the steps of his uncle, José Agustin Caballero. Luz y Caballero, however, realized afterward that the priesthood was not his calling. In spite of his decision he remained at the seminary. He studied philosophy and law at San Carlos under the guidance of Fr. Felix Varela. After graduation, he substituted for José Antonio Saco as a professor at the seminary (Baez 1974, 340-342). He focused on the education of the younger generations and opened several schools in La Habana. Until the day he died he directed one of the schools he had founded, El Salvador. He introduced into elementary education what he called método explicativo, which described in his own words: "consiste en hacer discurrir a los alumnos sobre cuanto leen, explicándoles palabras por palabras, según va siendo necesario para la inteligencia del discurso..." (Baez 1974, 341). He was more concerned with the proliferation of authentic and original ideas that with the repetition of the old ones.

Luz y Caballero studied, and organized the foundation of a school for teachers as a part of a Cuban institute that would promote national over foreign ideas and organizations. He participated enthusiastically in the activities of the Sociedad Económica Amigos del Pais, and through it he formulated his political opinions in favor of the independence of Cuba and against slavery. Those ideas gained him the enmity of some members of the Spanish government who never found a way to prosecute him (Baez 1974, 341). 
Another memorable Cuban who studied at the seminary was Cirilo Villaverde (1812-1894). He received a Baccalaureate in Law from San Carlos in 1832. Villaverde's antislavery sentiments and his aversion to the Spanish crown forced him into exile. He later became an annexationist through his personal contacts with Narciso Lopez, whom he had met in 1846 (Baez 1973, 83-84).

In 1882 he published the final version of his novel Cecilia Valdés. The importance of his novel rests not only on its literary quality but also on the thorough description of La Habana of the nineteenth century, its traditions, and social relations. In it, Villaverde expressed his revolutionary ideas, his discontent with slavery, with the stratification of Cuban society, and with the unjust treatment of the marginalized. $\mathrm{He}$ died in New York, but his work and patriotic ideas transcended his death as a proof of true Cubania. As expressed in his last will, his body was returned to Cuba and buried there (Baez 1973, 83-84).

The Catholic Church left its mark on the formation of the Cuban nation and its identity through the men that studied at the seminary San Carlos and San Ambrosio. It also influenced the eventual independence of Cuba from Spain through the ideas imprinted in the minds of those men who studied at San Carlos, such as Carlos Manuel de Céspedes. Many important treatises written during the nineteenth century emerged from those cloisters, such as Lecciones de Filosofia, and Misceláneas, by Varela, all the works of José Antonio Saco, as well as other writings such as Cecilia Valdés, by Cirilo Villaverde (Fernández Soneira 1997, 109).

The seminary was also the cradle for important organizations such as the Sociedad Patriotica de la Habana, presided over by bishop Espada (Leal 1997, 100). 
There was also a symbiotic relationship between San Carlos and La Sociedad Económica Amigos del País (SEAP) "which was sort of a nervous system to the organic whole of the nation" (Guerra y Sánchez et al. 1958, 389). The ideas emerging from the relationship that evolved between San Carlos, SEAP, and Sociedad Patriotica caused political changes on the island. They were of extreme importance and influence for the development of Cuban society as the members of those organizations promoted and supported educational and political reforms in Cuba (Segreo Ricardo 2000, 141-142).

From the cooperation between the SEAP, the professors and students of the seminary, and bishop Espada, many important institutions and organizations emerged such as the Botanical Garden, the San Alejandro Painting School, the first public libraries on the island, the Nautical School of Regla, the school of Obstetrics, and numerous schools that could be attended by children at no cost (Segreo Ricardo 2000, 141-142). The Church, through José Agustín Caballero, also influenced the role of El Papel Periódico de La Habana. ${ }^{9}$ The paper was a catalyzing venue for the evolution of the Cuban national identity as well as the eventual Cuban independence wars (Buch Sánchez 1999, 97).

\section{Decline of the Seminary}

The pro-Cuban political stances of the Church and the splendor of the seminary during this period were possible, in part, because of bishop Espada's support, enthusiasm, and degree of identification with the Cubans and their cause. They were also influenced by the passion for Cuba, the guidance, and the confidence of priests such as Varela and Caballero, among others. Consequently, upon their absence, and aggravated by the 
expropriating laws of Mendizábal ${ }^{10}$, San Carlos' prominence and the Church's active role in Cuban society slowly diminished ${ }^{11}$ (Leal 1997, 100).

The historical conditions that followed did not contribute to the continuity of the proliferation of liberal ideas coming from the Church on the island. Those were years in which "cayó sobre la iglesia en general la bruma espesa del abandono y del silencio..." (ENEC 1987, 37). Spain, in an effort to discredit the clergy and weaken the Church's influences over the Cuban population turned against the Church. The crown's hostility was a form of punishment for the Church's role in the propagation of ideas critical of the Spanish control of the island. The government accused several priests and bishops of conspiring against the crown. Many religious personnel were deported and others sentenced to death (ENEC 1987, 37-39; Segreo Ricardo 2000, 154-162).

The government reduced significantly its support for the Catholic Church and especially for the seminary. It ordered the closure of the seminary's Law and Math departments. In addition, the crown ordered an increase in the number of Spanish priests in Cuba. During the Desamortización de Mendizábal ${ }^{12}$, the government expelled from the island the religious orders, whose members were mostly Cubans, and secularized the university. These measures diminished the number of native religious vocations and created the general idea that the Church supported the status quo of the island (ENEC 1987, 37-39; Segreo Ricardo 2000, 154-162).

The advent of the independence wars, initiated by Carlos Manuel de Céspedes in 1868 and the subsequent years did not help the Church. The Catholic Church by then was ruled by bishops for whom the allegiance to Spain more than a requisite was almost a personal trait. Many more priests fled the island and many others who had been arrested 
for supporting Cuba's independence were killed or deported. There were still many others who joined the independence wars, reaching high ranks within the insurgent army (Céspedes García-Menocal 1996, 4-6; Testé 1975, 83).

In 1871 , because of lack of economic support and of candidates to the priesthood, and also due to the decrease in the number of classes taught at San Carlos, the Real Colegio Seminario was reduced to a mere Colegio de Segunda Enseñanza. It was no longer affiliated to with the university (Buch Sánchez 1999, 92).

During the last decades of the colonial period the Spanish monarchs ordered the Church's hierarchy to force the clergy and laity to reduce considerably their political actions. Their activities were limited to social concerns such as education, health, and charitable proceedings. Those were the spheres left almost unattended by the government and deeply affected by the wars. To further limit the Church's ability to affect society positively by ordaining Cuban priests, the Seminary ceased functioning as an educational institution in 1896 . The building was turned into a hospice to give refuge to orphans and to the dispossessed (Buch Sánchez 1999, 93).

The closing stages of the colonial period, full of wars, exodus, and silence, overshadowed the proactive role played by priests such as Las Casas, Espada, and Varela. The Catholic Church in Cuba would arrive at the next period of its history, in a state of extreme poverty and without qualified priests. It was also perceived as being against Cuban independence due to the political stances of some members of the Catholic hierarchy. The religious personnel who had supported the independence of Cuba and had fought against Spain went unrecognized. 


\section{Notes}

${ }^{1}$ It must be noted that Cuba was ecclesiastically structured as only one archdiocese, Santiago de Cuba. It was not until 1787 that San Cristóbal de La Habana became a diocese (Testé 1970, 20).

${ }^{2}$ Fernandina back then.

${ }^{3}$ Usually called the New Laws of 1542.

${ }^{4}$ The efforts leading to the establishment of a seminary in Cuba date back to the last years of the XVI century, atone with the crown's mandates. In 1592, in a Royal Decree king Felipe II ordered the bishops and archbishops of the Indies to found, support, and preserve Colegios Seminarios for the formation of priests, as indicated by the Council of Trent (1545-1563). In the same decree he mandated the governors and viceroys of all his territories to support morally and economically the Church in its efforts to found such institutions. However, because La Habana was not yet a diocese, the foundation of a seminary would not take place until a century later (Buch Sánchez 1999, 74).

${ }^{5}$ The Spanish currency of the time.

${ }^{6} \mathrm{He}$ was also the founder in 1722 of the Seminary San Basilio Magno in Santiago de Cuba (Fernández Soneira 1997, 1:62) and the orphanage Casa Cuna or Hogar de Beneficencia Valdés in 1710 (Testé 1969, 120).

${ }^{7}$ There is an exhaustive work on the causes for the expulsion of the Jesuits and the effect it had on the island (García Rodriguez, 2000).

${ }^{8}$ It will be chaired later by Fr. Varela

${ }^{9}$ First appeared in October 24, 1790 (Guerra y Sánchez et al 1958, 271)

${ }^{10}$ On October 1835, a decree of the Spanish government, inspired by Juan de Mendizábal, minister of finance, suppressed most monasteries in Spain and its possessions. In Cuba the implementation was gradual. By 1842 the University of $\mathrm{La}$ Habana had been secularized and the friars expelled by 1848 (Larrúa Guedes 1998, 320322)

${ }^{11}$ There were other prominent figures such as Antonio María Claret (1807-1870), archbishop of Santiago (1850-1859), today a saint of the Catholic Church. He was the founder of the congregations of Claretianos and Claretianas, and an advocate for agrarian reforms benefiting the Cuban peasants as well as a critic of racial inequalities (Lebroc Martinez 1985, 17). Another prominent figure, who worked closely with Claret, was Jerónimo Usera (1810-1891), founder of the Hermanas del Amor de Dios, a congregation 
dedicated to the education of children and adolescents (Fernández Soneira 1997, 240242). Neither the seminary nor the Church, however, regained the prior influence on Cuban society during the remaining years of the colony.

${ }^{12}$ See endnote 10. 


\section{CHAPTER 3}

\section{A Church in between, 1898-1902}

This chapter describes the history of the Catholic Church in Cuba during the four years of the United States first occupation of the island. During that time the Church remained active, but it was also disoriented because of the foreign nature of the occupying forces and the provisional character of the occupation government. At the same time the recent freedom from the regulations of the Patronato Regio presented the Church with the opportunity to design new strategies to play its role within the new society as an independent (except from Rome) institution.

During this period the Church focused on its internal reorganization. It was characterized by the emergence of a reciprocal communication between the hierarchy and the clergy, and between the clergy and the laity that culminated in mutual support. This time is also marked by the ability of the Church to voice its demands, to adapt to new governmental dispositions, and to compete with other religious and secular institutions. Without governmental interference and without economic support the Church also needed to develop a series of strategies to become self-sufficient.

\section{The transition between the colony and the United States occupation}

In 1898, after three decades of independence wars, Cuba obtained its independence from Spain. The island, however, was not able to secure a national government as it was immediately occupied by another imperial power: the United States. The transfer from one power to the other was humiliating for many men and women who had fought for their independence. Cubans were not invited nor allowed 
into the transitional meetings and ceremonies, which further offended them (Larrúa Guedes 1996, 181).

Nonetheless, a large part of the Cuban insurgent forces, over two thousand men and women, had their own celebration. In a demonstration of the religious sentiments of the Cuban insurgents, general Calixto García Iñiguez, uninvited to the celebrations in Santiago, ordered his troops to concentrate at El Cobre. The small town on the outskirts of Santiago with a temple dedicated to Our Lady of Charity, highly revered by the Cubans. There, with a solemn Te Deum and a mass, they celebrated the triumph of the Cuban armed forces over the Spaniards. That religious/political act became later known as La Declaración Mambisa de la Independencia del Pueblo Cubano (Larrúa Guedes 1996, 181). The Cuban priest Desiderio Mesnier celebrated the mass. He assured those present at the ceremony that La Virgen de la Caridad would help her Cuban people to build and consolidate a Christian Republic (Fernández Santalices 2001, 89).

In a concurrent act of emancipation, the Cuban clergy defied the Catholic hierarchy. They resented that at the time of the island's independence from Spain, Spanish bishops headed the two Cuban ecclesiastical provinces, Santiago and $\mathrm{La}$ Habana ${ }^{1}$. The clergy's opposition to the bishops, however, was not based on the quality of their pastoral work (Testé 1969, 163-164) but on their lack of support for the Cuban independence cause (Fernández Santalices 1998, 5).

The Cuban clergy demanded the bishops' resignation. On September 20, 1898, fifty-two Cuban priests wrote a letter in which they expressed their solidarity with the Cuban people as they had also suffered ignominies under the Spaniards. They added that the only reason they received such a treatment from the bishops was because of the love 
for Cuba professed by the Cuban clergy. The undersigning clergy also denounced the unjust deportation of some religious personnel, the arrest of some, and the killing of others. "That is why" they wrote "there are not many of us left, because they (the Spaniards) have wanted to exterminate us so that the Spanish clergy can rule exclusively over the Cuban consciousness and hammer our chains..." (Belda Mas 1999, 56).

In the document they asked Rome for the appointment of two new bishops so that they could respond to the new reality on the island and administer the Catholic Church in Cuba. They were very specific in their request: the appointees had to be Cubans (Fernández Santalices 2001, 89).

The Cuban clergy was aware of the need of establishing a Church guided by Cubans and not by foreigners. Conscious of the historical moment in which they were living, they tried to seize the opportunity to Cubanize the church. The Cuban priests wanted to establish a Church that represented its own interests, the interests of the Cuban population, but also a Church that would reflect the island's new political situation. Some documents of the time refer to this as a need to establish a national Church, which has been misinterpreted by some authors as an attempt to create a Church independent from Rome (Ibarra 1981, 101).

That was never the intention of the Cuban clergy; they only wanted native religious leaders for Cuba. The fact that honorable men such as Calixto García and Salvador Cisneros Betancourt made public their request for Cuban bishops for the Church in Cuba, was by no mean a call for a religious schism. It was their way of honoring the Cuban clergy that had sided with them during the independence struggle, as well as an opportunity to voice their anti-colonialist ideas (Fernández Santalices 1998, 6). 
Rome wanted to appease the Cuban clergy, but was also conscious of the new political situation of the island; Cuba was in the hands of the United States. Immediately after the abolition of the Real Patronato as a consequence of the Treaty of Paris, Rome recalled both bishops, and assigned two others to the vacant dioceses. Those men were thought by Rome to be more likely accepted by the Cubans (Maza Miquel 1999, 219225; Fernández Santalices 1998, 5).

In a diplomatic move, Rome appointed a Cuban bishop for Santiago, Msgr. Francisco de Paula Barnada, a native of the city. The Holy See was aware that the eastern region of Cuba was where most of the independence wars had taken place. Santiago was also the region where most of the insurgents still resided, and it was the primary archdiocese of the island. As expected, the Cubans gladly accepted the archbishop for Santiago. After all, he was not only Cuban but also a known sympathizer of their independence cause (Maza Miquel 1999, 219-225; Fernández Santalices 1998, 5).

On the other hand, the Pope named an Italian diplomat for the capital, where the United States interventionist government was located. The new pastor of La Habana, Msgr. Donato Sbarreti, was publicly rejected by the Cuban clergy as well as by the Cuban leaders of the insurgent movements. Máximo Gómez, Salvador Cisneros Betancourt, and the Cuban priests Luis Mustelier and Desiderio Mesnier were among those who adamantly opposed bishop Sbarreti's appointment (Maza Miquel 1999, 219225).

In 1900 Calixto García and Salvador Cisneros Betancourt became part of the newly created Comité de Propaganda y Acción. The committee obtained over 200 signatures and sent a document to the Holy See requesting that the Cuban priest Luis 
Mutelier be made bishop of La Habana (Maza Miquel 1999, 222). In July of the same year, thirty-six Cuban priests sent another letter to Rome asking for the removal of Sbarreti. The number of protests and the number of signatures increased (Maza Miquel $1999,224)$.

Regardless of the Cubans' public discontent, Rome kept Sbarreti as the bishop of La Habana for as long as Cuba was occupied by the United States. Sbarreti had been appointed because of his previous experience as Auditor at the Apostolic Delegation in Washington. Rome believed that he was the most suitable candidate to deal with the temporary government of the island (Leiseca 1938, 209).

The Church was concerned with the future of the country, and with its own role within the new society. The legal separation from la madre patria meant the loss of its socioeconomic status. It also created severe limitations for the Church as a provider of social services. The lack of Cuban priests and of candidates for the priesthood further aggravated the viability of the Church in Cuba. As an institution, the Church entered into the period of United States occupation pervaded by the same uncertainties as the rest of the Cuban institutions.

\section{The Church under the United States occupation}

The arrival of the new military government from the United States headed by General John Brooke marked the departure of most of the Spanish government officials and of many Spanish citizens in general. With them left a large number of religious personnel that had sided with the crown during the independence wars. This aggravated the already mentioned economic and personnel pauperization of the Catholic Church in Cuba (Larrúa Guedes 1996, 172-181, 183; ENEC 1987, 38-39). 
The new governor of the island introduced a series of sociopolitical and religious measures intended to strengthen North America's cultural and political supremacy over the "new possession". Those measures significantly affected the Catholic Church. Influenced by the United States Protestant ideology, Brooke substituted religious with civil control of education and healthcare, further restraining the Catholic Church's abilities and resources. On the other hand, he gave green light to the expansion of nonCatholic Christian beliefs and practices (Kirk 1989b, 37; ENEC 1987, 38-39).

For instance, Brooke eliminated the Catholic Church's monopoly on marriage ceremonies by establishing a civil marriage as the only legally binding act ${ }^{2}$. In addition, Brooke declared the separation of Church and state. Thus the government would not fund the Church. Following this notion of separation of Church and state, Brooke also prohibited religious education as well as prayer in public schools, and separated religious personnel from hospitals and other public health care institutions (Kirk 1989b, 37).

Those procedures were in harmony with the trends of positivism, secularization, atheism, and anticlericalism in existence throughout the world at the turn of the century (McCarthy 1994, 36). In Cuba, they were reinforced by the increasing number of Protestant churches coming from the United States.

The measures implemented by Brooke and the newly introduced Protestant competition forced the Catholic Church in Cuba to a holistic renewal. The Church acknowledged the need to reinvent its role as a social activist to reach a greater number of faithful Catholics in order to perform its historical responsibility with the people of God. They also realized their impoverished economic situation and the inevitability of 
developing fundraising strategies. Working to obtain funding and reinventing its social role, however, required additional personnel.

The Church hierarchy realized that the best way to increase the number of clergymen, as the seminary was still inactive, was to invite the religious orders and congregations previously expelled from the island during the Desamortización de Mendizábal, to return. The bishops also encouraged orders and congregations never before established in Cuba to found houses throughout the island (Leiseca 1938, 209215).

The immediate goal of the Church's hierarchy of increasing the number of religious personnel was hindered by the lack of economic means required to purchase and repair houses and convents. Msgr. Sbarreti, making use of his diplomatic abilities, began negotiations with Brooke in order for the Church to be compensated for the properties confiscated by Spain (Leiseca 1938, 209-215).

Sbarreti was not alone in the negotiations. Rome, in another diplomatic move, had named Msgr. Placide Chapelle, who until them was the Archbishop of New Orleans, as the Apostolic Delegate for Cuba and Puerto Rico (Lebroc 1985, 75). In spite of Sbarreti's diplomatic skills and the collaboration of Chapelle, the negotiations would not be finished until a few years later (Leiseca 1938, 209).

Towards the end of the United States occupation, and as the idea of establishing an independent republic stopped being a utopian ambition, the development of a constitution became a priority. The Catholic Church in Cuba, once again, was plagued by the uncertainty about its legal status within a new form of government. 
The Church's uncertainty was intensified during the constitutional assembly inaugurated on November 5,1900. At the constitutional debates, not just the Church but the role and place of religion on the island were at stake. An important issue addressed was the inclusion of an invocation to God in the preamble to the constitution. Several well-known figures, such as Salvador Cisneros Betancourt and Juan Gualberto Gómez, opposed such an invocation. Others, such as Manuel Sanguily and Pedro González Llorente, defended it. At the end, the resulting constitution included the invocation of God's favor in its preamble. Other articles stipulated religious freedom, the separation of Church and state, and established that the government would not finance religious activities (Aragón 2002, 2; Fernández Santalices 2001, 94).

The constitution clearly turned the Catholic Church into one more religious organization on the island without special privileges. The new legal situation of the Church, however, was a catalyst. Without access to people's education, without control over marriage ceremonies - and the remuneration they represented -, lacking governmental financial support, and facing strong competition from other religious groups, the Catholic Church in Cuba was powerless as it entered into the next period of Cuban history.

Lack of power, however, was not a negative factor as it placed the Church at the same level as the emerging Cuban state and its institutions. The Church and the state were equally inexperienced in self-government, deficient in economic funds, and challenged by the needs of the rapidly increasing Cuban population. Overcoming these challenges would be the ultimate test for their coming of age. 


\section{Notes}

${ }^{1}$ The archdiocese of Santiago de Cuba was ruled by Msgr. Francisco Sáenz de Urturi, and the diocese of San Cristóbal de La Habana, by Msgr. Manuel Santander Frutos (Fernández Santalices 1998, 5).

${ }^{2}$ Although civil registers were already in place, the new measure established that religious matrimonies had to be legalized by a civil ceremony in order to be legal, and that religious marriages were optional. 


\section{CHAPTER 4}

\section{The Catholic Church During the Republic}

This chapter, the focal point of the thesis, is divided into two periods. The first one, called Reorganizational Period, originates with the issuance of the 1901 Constitution, and ends before the establishment of the new Constitution of 1940. This is a time in which the Church freed from the impositions of the Spanish Patronato and legalized by the constitution employed its resources in recovering economically, growing in numbers, and establishing a noticeable presence.

The second, the Sociopolitical Period, commenced with the national efforts for the development of a new constitution and finished with the arrival to power of the government of Fidel Castro in 1959. Nonetheless, the second period is extended to 1962 when the Church personnel and properties were decimated, marking the end of its growth, and the minimization of its role as a social agent. It has been classified as the Sociopolitical Period because it begins and ends with a significant external interaction between the Church and the government in turn due to the sociopolitical changes taking place in the island.

\section{The Reorganizational Period (1902-1939)}

"Llegó el día 20 [de mayo]; toda de fiesta y de gala, La Habana presenció las ceremonias del traspaso de poderes. Un cubano asumía el mando y un gobierno militar se alejaba de las costas de Cuba. En lo alto del Morro, resplandecía sola la bandera que había guiado a generación tras generación de cubanos. Mirándola, Máximo Gómez, el guerrero de treinta años de sacrificios en quien se sintetizaban los logros realizados, pudo exclamar: "Creo que hemos llegado" (Baez 1975, 634) 
The end of the first United States occupation of Cuba and the election of Tomás Estrada Palma as the first president of the Republic marked the beginning of a new era for Cuba. For the Catholic Church it was also a new beginning. As an institution legalized by the Constitution of 1901 , the Church was prompted to stop being merely the Church in Cuba to become the Church of $\mathrm{Cuba}^{1}$.

The Church needed to expand throughout the country in order to reach a larger number of faithful Catholics as a source of both financial and of moral sustenance. The Church turned to Rome for help and received it. Towards the end of 1901, Rome named bishop Sbarreti Apostolic Delegate to the Philippines, and in 1903 promoted the Cuban priest Pedro Ladislao González Estrada to the bishopric of La Habana (Lebroc Martinez 1985, 30). The response from Rome meant that the insistence on the part of the Cuban clergy and laity to have Cuban bishops had finally paid off.

In addition, the Holy See proposed the expansion of the local Church through the creation of new dioceses. Between 1900 and 1912, the Church in Cuba tripled its administrational religious divisions, from two to six; a sufficient growth given the population at the time and the size of the island (Meier et al. 1995, 343-344). In 1903 the dioceses of Pinar del Río and Cienfuegos were created, headed by the Cuban bishops Braulio Orúe Vivanco and Aurelio Torres Sainz respectively (Lebroc Martinez 1985, 45$48)$.

The dioceses of Matanzas and Camagüey were created in 1912; however, the men chosen as bishops for these dioceses were not Cuban. For Matanzas, Rome elected the Antillean (St. Thomas) priest Charles Warren Currier because of his knowledge about the history of the Catholic Church in Cuba, as he had written a book on the subject. He 
resigned a year later without gaining acceptance by the Cuban clergy. Severino Sainz Bencomo, born in Pinar del Río, took over the direction of the diocese of Matanzas (Lebroc Martinez 1985, 27, 36). The Basque priest Valentín Zubizarreta was selected for the diocese of Camagüey. He successfully served the Cuban Church as bishop for different dioceses until his death in 1948. His long permanence as bishop in Cuba was because of his love for the Cuban people and for the island he called home demonstrated by his hard work and dedication to the well-being of Cubans (Lebroc Martinez 1985, 3638).

Due to the rapid increase of the population and to the number of parishes being established in the capital, in 1903, Rome appointed Fr. Buenaventura Broderick as auxiliary bishop of La Habana (Leiseca 1938, 213). This bishop, an American citizen, had been sent to La Habana by Rome because the Platt Amendment still connected Cuba to the United States. Therefore, a United States citizen could be more effective in any eventual negotiation with Washington. Although Broderick efficiently performed his auxiliary duties, the Cuban clergy did not accept him either. Broderick resigned in 1905. The Cuban priest Severino Sainz replaced Broderick (Leiseca 1938, 213; Testé 1969, 399-400).

The new bishop of La Habana, González Estrada, received the support of clergy and laypersons alike. He worked tirelessly for the successful reorganization of the Church. He focused on several important issues such as: finishing the negotiations for reimbursement that had been started by Sbarreti with the government; increasing the number and quality of medical and educational institutions; reopening the seminary and increasing the number of native vocations; rebuilding temples and establishing new 
parishes; and working intensively for the socioeconomic betterment of the rapidly growing working class. By the time he resigned as bishop of the diocese in $1925^{2}$ (Lebroc Martinez 1985, 30), González had successfully accomplished what he had set out to do.

In order to achieve its goals, the Church needed funds. The negotiations started by Sbarreti with the interventionist government of Brooke, and finished by González and the new occupational government of Magoon, provided the Church with additional economic solvency to continue its reconstruction throughout the island (Lockmiller 1969, 138-143).

The money received was distributed among the different dioceses and used, mostly, for the reconstruction of churches, and the establishment of religious houses, convents, and schools. The buildings were dedicated to education, the care of the old, the mentally and physically ill, and of the orphans and incapacitated:

"En 1904 los escolapios fundaron un colegio en Cárdenas, y en 1910 abrieron los de La Habana y el Cerro. Los Hermanos de La Salle abrieron un colegio en el Vedado en 1905, y poco después los de Marianao y Carlos III. Por su parte los Jesuitas ${ }^{3}$ le dieron mayor relieve al Colegio de Belén levantando el gran centro educacional de Marianao, y las Hermanas Oblatas de la Providencia, en 1908, fundaron un colegio en Cárdenas y una academia para adultos pobres. Las Hijas de la Caridad ampliaron la labor del colegio La Inmaculada y fundaron nuevos colegios en Marianao (1912), Regla (1913), Güira de Melena (1915), San Antonio de los Baños (1916), así como el Asilo Menocal y Greche del Vedado (1914), el Asilo Truffin (1918) y el Asilo Maria Jaén de Zayas (1921)..." (Larrúa Guedes 1996, 194)'

In 1904 Msgr. González ordered that the Boletin Oficial de la Provincia Eclesiástica de la República de Cuba (Boletín hereafter), which had ceased circulation in $1899^{5}$, be published again. The bulletin became the primary avenue for the hierarchy to 
communicate officially with the Cuban society through edicts and pastoral letters (González Estrada 1904, 1).

Boletin was a monthly publication available to laypersons and clergymen alike. It had several sections such as Sociologia, Variedades, Pastoral, Derecho Canónico, and many others that fluctuated throughout its existence ${ }^{6}$. This periodical opened a channel for the Catholic hierarchy to voice its opinions. For example, it made public the Church's disagreement with governmental measures. It warned Catholics of the rapid spread of Protestantism and anticlericalism. The Boletín also offered a vehicle to officially recognize, approve, and praise organizations and individuals working for the benefit of society ${ }^{7}$.

This periodical published the results of monetary contributions by parishes, answered letters questioning legal and moral issues, and even published the grades of the seminarians. More importantly, inasmuch as it made the people aware of the Church's positions and actions, Boletin became a way for the community to evaluate the effectiveness of the Church ${ }^{8}$.

In 1905, bishop González published a letter, announcing the reopening of the Seminario San Carlos and San Ambrosio, closed as an educational institution since 1896. It was a necessity for the Church, and an important tactic aimed at providing education for the future Cuban religious leaders. These leaders would have sufficient charisma to mobilize the people, reconstruct the Church, and eventually launch the re-evangelization of the island (Variedades $1905,235-237$ ).

Among many other dispositions, the letter stated the requirements for acceptance into the seminary, and announced that for the available scholarships "serán preferidos los 
hijos de padres pobres" (González Estrada 1905, 115). The first class of the seminary during the Republic opened on September of 1905 with 21 students, twenty of them received full scholarships (González Estrada 1905, 209).

During the pontificate of bishop González numerous parishes were established. They were created in neighborhoods in the outskirts of La Habana as well as in the rural areas of the province. Those were zones previously ill attended by the Church. They were neighborhoods inhabited by a rapidly growing working class, a phenomenon that was increasingly becoming the focus of attention of the Church. Areas such as Marianao, Arroyo Arenas, Quivicán, La Salud, and many others, saw the establishment of parishes, and, for the first time, the presence of priests and/or nuns full time (Leiseca 1938, 221222).

González believed in, literally, opening the doors of his office to receive anyone seeking help or advice (González Estrada 1904, 24-25). Besides the regular duties of a head of a diocese, his pastoral work focused on making public appearances (pastoral visits) at the most remote neighborhoods and towns of his territory. His presence attracted large crowds of people. Taking advantage of the multitudes, González preached about the need for the rebirth of the Catholic faith and morality in Cuba. He also seized the opportunity of these visits to administer the sacraments of initiation (baptism, communion, and confirmation) to numerous people (Antoine 1909, 94).

His presence at a particular parish inaugurated the Misiones Parroquiales. Although the statutes for theses missions were officially defined by bishop Ruiz in 1926, a year after Msgr. González resigned, they were initiated during González Estrada’s pontificate. They were simply the evangelization of the island starting where it was 
needed the most, the rural and suburban areas. The Misiones were the first step to the massive incorporation of laypersons into the active life of the Church ${ }^{9}$ (Testé 1975, 345).

The statutes published in 1926 officially authorized lay men and women to preach the Gospel and visit the ill, which they had been doing already. The purpose of the Misiones was to end with religious ignorance as well as with the "vicios contrarios a la justicia" (Testé 1975, 345). The lay missionaries were in charge of the religious preparation of the population, i.e. catechism. Once people were religiously prepared they received the sacraments of initiation either from the bishop during a pastoral visit, or from a priest during a religious feast (Testé 1975, 344-350).

The Misiones Parroquiales were fruitful from the time they were initiated by González. For instance, in Jaruco in January 1910, during a bishop's visit, 1,235 people were confirmed (Un Católico 1910, 66). A month later, in San José de Las Lajas, where González had previously been a pastor, 1,400 persons were confirmed, 437 went to confession, and 117 received First Communion (El Corresponsal 1910,67). Between March 14 and 21, 1915, during the visit to Iglesia y Parroquia del Pilar, in El Cerro, 225 adults, and 200 children received First Communion, 80 were baptized, 940 were confirmed, and 6 couples were married (De Casa 1915, 113-114).

The growth of the Church was also noticeable in the rest of the country. The ecclesiastical division of the island into six dioceses implied that the efforts to reconstruct and inaugurate new parishes and to promote native vocations were the sole duty of the particular prelate in charge of the diocese. All the Cuban bishops, however, worked closely, supporting each other's efforts to expand the Church on the island. There were 
fundraisings organized at well-established dioceses such as La Habana and Santiago to finance the new dioceses' growth (Leiseca 1938, 235-250).

Numerous orders and congregations founded convents, clinics, and schools throughout Cuba. In Pinar del Río, for example, “...los PP. Escolapios, las MM. Escolapias, y las religiosas del Inmaculado Corazón de Maria establecieron varios colegios...las Hermanitas de los Ancianos Desamparados, las Hijas de la Caridad, y las Hijas del Calvario abrieron asilos para ancianos..." (Leiseca 1938, 236).

In Cienfuegos the Jesuits, Franciscans, Dominicans, and Missionaries of St. Therese established and/or expanded houses dedicated to education and to the care of the sick (Leiseca 1938, 238). The seminary of San Basilio in Santiago de Cuba was reopened on October 28,1917 , in order to provide young men in the eastern side of the country with the first years of education towards the priesthood, but also to alleviate San Carlos' growing number of candidates to the priesthood (Ambrosio 1917, 718-719).

Cuba also saw the establishment and/or expansion of male and female religious congregations founded either in Cuba, by Cubans, or for Cuba. Some of those congregations were the Claretianos and Claretianas, Hermanas del Amor de Dios, Instituto Misionero de la Caridad del Cobre, Cooperadoras Diocesanas, Hermanas de los Pobres Inválidos y de los Niños Pobres, Religiosas del Apostolado del Sagrado Corazón de Jesús (Apostolinas), and the Oblate Sisters of Providence (Testé 1973, 354-727). With the exception of the latter, the rest of the congregations were founded as a response to the acute social problems affecting $\mathrm{Cuba}^{10}$. 


\section{Black nuns for black girls}

Although most congregations accepted into their schools and academies persons of all ethnic and social classes, racism was noticeable in Cuba, and black children were not common in Catholic schools. There was, however, one congregation with the particular charisma of "being a congregation formed by women of color ... working for the Christian education of black children" (Testé 1973, 725). The Oblate Sisters of Providence, founded in 1829 in the United States by the black Cuban Mary Elizabeth Lange (1798-1892), became the first religious congregation of black women in the history of the Catholic Church (Testé 1973, 724).

The congregation was founded to serve the needs of the black and migrant ${ }^{11}$ communities of Baltimore, in the United States. After seven decades of difficulties, tirelessly going against the social currents in the United States ${ }^{12}$ because of their charisma and racial composition, the Oblates arrived in La Habana on November 10, 1900. Msgr. Sbarreti invited the sisters to join the reconstruction efforts of the Church in Cuba, especially to take care of the marginalized black sector of the Cuban population (Testé $1973,724)$. It was also Sbarreti's way of honoring the memory of the congregation's Cuban founder.

The Oblates and their efforts to establish colleges and academies throughout the island were welcomed by every bishop ${ }^{13}$. At the institutions created by the sisters, black Cuban girls received free, bilingual education, supported by private and governmental donations $^{14}$. For instance, in 1940, President Batista donated a property of 12,000 square meters for the construction of one of the schools. The project was subsidized by $\$ 100,000$ pesos from a Sorteo Extraordinario de la Lotería Nacional, $\$ 15,000$ donated 
by the Holy Father Pius XII, and $\$ 2,000$ given by Msgr. Manuel Arteaga y Betancourt, Archbishop of Havana. A large number of the girls taught by the "black nuns" (Eguino 2000), as they were popularly known, became teachers in order to serve the needs of their country, as stated in testimonial letters by former students (Fernández Soneira 1997, 380390, Testé 1973, 724).

\section{For the love of God... and for the children}

The Hermanas del Amor de Dios were founded in 1864 by the Spanish priest Jerónimo Usera, who lived and worked in Cuba from 1848 to 1891 . Due to the statutes imposed by the Patronato Regio, and to some family ties of the founder to a bishop in Spain who expedited the foundation, the congregation was organized and approved in Spain. The sister's missionary target, however, was not Spain but Cuba where they arrived in 1871 (Fernández Soneira 1997, 240-242; Testé 1973, 650). The purpose of the congregation was to open schools for the elementary education of Cuban girls from all social levels "ya que tanto se ha hecho en favor de los varones en la Universidade institutos" (Fernández Soneira 1997, 243). The social needs of Cuba, nonetheless, forced the sisters to expand their duties.

Seeing the devastating effects the wars had on the younger generations, the Hermanas del Amor de Dios, opened houses to feed and shelter orphan and disabled boys and girls without regard to their race. Their decision to serve the marginalized sectors of society led them to establish themselves in rural areas and in the poorest sections of the cities $^{15}$ (Fernández Soneira 1997, 243). In spite of the lack of economic resources the sisters made every possible effort to maintain high quality services (Fernández Soneira 1997, 250). 
The sisters' founder also created the Academia Gratuita de Tipógrafas y Encuadernadoras, later supported and run by the sisters. Its purpose was to professionally educate young women to work in the newspaper industry. They also founded and sustained the Sociedad Protectora de Niños de la Isla de Cuba. The society, which later expanded its work into Puerto Rico, had the function of protecting, clothing, instructing, defending, and providing sanitary assistance to the children, regardless of race or other social condition (Fernández Soneira 1997, 251; Testé 1973, 646, Cartaya Cotta 2000, 19-21).

\section{The Dominican Family, educating at all levels}

The Dominicans' commitment to the defense of the socially marginalized, and their dedication to quality education had been a constant in Cuba since their arrival in $1511^{16}$. Expelled from the island in 1845 , because of the expropriation laws of the Desamortización de Mendizábal, they returned to Cuba in 1898 and joined the Church in its efforts to serve the people (Larrúa Guedes 1997, 209,215).

In addition to their regular pastoral work, they provided religious attention to prisoners. The friars and nuns created several schools and academies in several Cuban cities. They collaborated with other orders and congregations such as the Marist Brothers, the Brothers of La Salle, and the Oblate Sisters of the Providence, for their establishment in Cuba (Fernández Soneira 1997, 42-47; 310-314; 36-372).

The Dominican cloister nuns donated half of their convent located in Paseo and $25^{\text {th }}$ street, in El Vedado, for an elementary and secondary school for the poor. The students received free education, breakfast and lunch, financially supported by the nuns. They also paid for at least ten scholarships each year for the education and development 
of priests at the seminary (Eguino 2000). The nuns also cooperated with the friars by subsidizing the introduction in Cuba of parochial school education ${ }^{17}$. These schools offered free elementary education to the children that lived in the geographical area assigned to a particular parish. The schools were administratively and economically dependent upon the parishes, however, they received some financial aid from the dioceses and the government at the local and/or national level (Fernández 2002; Eguino 2000; Fernández Soneira 1997, 42).

The Dominicans opened five parochial schools in La Habana, two in El Vedado, and three in the surrounding poor workers' neighborhoods of La Timba, El Fanguito, and La Dionisia. The largest of all was the one adjacent to La Parroquia del Vedado, which operated since its inauguration in the 1920s at its full capacity of 500 children (Fernández 2002; Eguino 2000; Fernández Soneira 1997, 42).

The educational labor of the Dominican friars and nuns (be it the American, French, or Spanish branch) was also evident in other cities. In 1900, they founded the first Escuela de Comercio and the Escuela de Agrimensura in Cienfuegos (Fernández Soneira 1997, 44). In addition, seeing the importance of sugar production for the island's economy, and due to the lack of quality studies related to that process, they founded the Escuela de Quimica Azucarera (E.Q.A) in 1907, the first of its kind on the island (Memorias 1921, 121). The school was named after one of their own, Bartolomé de Las Casas, honoring the first advocate of the indigenous people of the Americas.

The Dominicans developed a curriculum based on the most advanced techniques for sugar production. They also furnished the labs with state of the art technology coming from France. The school, which soon evolved into an academy, worked at its full 
capacity since its inauguration. The friars had to remodel the buildings several times throughout the years in order to accommodate the constant increase in the number of students (Memorias 1921, 121-126; Eguino 2000; Fernández 2002)

The E.Q.A. was endorsed by the Cuban as well as the United States educational systems. Students graduated from E.Q.A. as Quimicos Azucareros or Peritos Químicos Azucareros and could transfer to North American universities in order to pursue a higher degree. A United States consul stationed in Cienfuegos certified their transcripts. Those who decided to remain in Cuba were in high demand, and even those not graduated yet from E.Q.A. were offered part time employment at sugar cane factories. The E.Q.A. contributed throughout the years not only to the competent education of Cubans, but consequently to the island's economy, which was profoundly dependent on sugar production (Memorias 1921, 121-126).

\section{Organizing the laity ${ }^{18}$}

In 1911, Pope Pius X called for the bishops and archbishops of the Catholic Church to increase the number of lay organizations. He decreed that Catholic bishops had complete authority over those organizations. In doing so, he set the basis for what later became known as Catholic Action, a term that denotes the collaboration of the laity in the apostolic work of the Church's hierarchy. His successor, Pius XI, made Catholic Action official in 1922, with the task of "animating society with a Christian spirit, especially the Catholic understanding of faith and morals" (McCarthy 1994, 53).

In his first encyclical, Ubi Arcano Dei Consilioi (On the Peace of Christ in His Kingdom), Pius XI acknowledged the need for a new evangelization initiative on a global scale. He also recognized the worldwide shortage of priests. Both conditions required an 
immediate solution, and the Pope proclaimed that Catholic Action was to help the priests and make up for their small numbers by multiplying their helpers among the laity (Ubi 57-59).

In Cuba, as the Catholic Church intensified its missionary work, and the number of Catholic educational and health related institutions augmented, more people entered into contact with the Catholic doctrines. The consequential emergence a numerous laity became a gratifying problem for the clergy. The people attending Church required more than participation in masses and in devotional practices, making the deficit in the number of priests a more pressing issue.

Following the Pope's directives, the clergy began to delegate some of its responsibilities to those that, albeit not religious personnel, were deeply involved in the Church. Even though Catholic Action was not formalized in Cuba until 1938, the emergence of a committed laity was a fact, and the Church, following its hierarchical tradition, needed to congregate and legitimize them (Fernández Santalices 1998, 33).

Numerous lay organizations were established that played a pivotal role in the efforts for the re-evangelization of the island during the following years. Many of those organizations were of a devotional (contemplative) character, such as Archicofradias del Santísimo Sacramento, and Adoración Nocturna (Testé 1975, 190-195). Others, however, were actively involved in social matters. Such is the case of the Orden de los Caballeros de Colón, founded in Cuba by North American Augustinians and a group of United States Knights of Columbus, in 1909. This "lay order" rapid growth was in part a response to the popular idea that "en Cuba la religión es cosa de mujeres". The Cuban branch of the Knights of Columbus proved to be a fruitful organization that economically 
supported the Church's projects, and gave the Church a masculine face (Fernández Santalices 1998, 22).

The Caballeros de Colón also played an important role on a political level. In the Unites States the Knights of Columbus, demonstrated their solidarity with their Cuban counterpart by lobbying "en contra de la subida de los aranceles del azúcar cubano y a favor del justo reconocimiento de la soberanía cubana sobre la Isla de Pinos" (Fernández Santalices 1998, 22).

The Cuban Catholic men, however, desired a Cuban organization, and in 1929 founded the Asociación de Caballeros Católicos de Cuba. This association resulted from the merging of several small associations of men to pool resources and better serve the Church and the nation. The association was defined as having a national lay-religious character with the purpose of offering religious education to men, as well as promoting Christian moral and family values in the island (Testé 1975, 350-352).

Contrary to the usual norm in Cuba, the Caballeros Católicos was an organization that emerged in the countryside. The association began in Sagua la Grande in 1929 with 407 members, then spread into the provinces, and arrived in the capital in 1930 . By the time it reached La Habana its membership was over 5,000 men. The association has been defined as the most successful organization working for the incorporation of Cuban males into the life of the Church. Its members have also been recognized as constantly offering their support to the patriotic efforts and activities of the Catholic Church in Cuba (Fernández Santalices 1998, 26).

Cuban women were also represented through an array of organizations working through the Church for the improvement of the nation. Among the most outstanding 
organizations, known (even to date) for their charitable work, and for the promotion of Catholic women's interests, were the Asociación de Católicas Cubanas (1919), Damas Isabelinas ${ }^{19}$ (1925), and Asociación de Maestras Católicas (1939) (Fernández Santalices $1998,22,23,27)$. These organizations were responsible for founding several institutions of outstanding significance. Such was the case of the maternity hospital "La Milagrosa" founded by Católicas Cubanas under the auspices of the Daughters of Charity of St. Vincent of Paul. The hospital, which offered healthcare to women before, during, and after pregnancy, was supported by a membership of over 15,000 women. The Casa Cultural Católica, founded by Damas Isabelinas also played an important role in the education of women. It was a nonprofit institution dedicated to prepare women for their successful entry into the labor market (Fernández Santalices 1998, 26; Testé 1975, 190195).

The Catholic youth in Cuba was also organized into different groups according to their age and occupation. In 1920 Fr. Manuel Serra, of the Escolapios, founded the Asociación de Jóvenes Católicos (that became the Club Católico Universitario in 1927) as the Cuban Catholic counterpart to the North American YMCA, of Protestant affiliation (Fernández Santalices 1998, 22). Brother Victorino de La Salle founded the Federación de la Juventud Católica Cubana in 1928. The federation was to bring together all the youth organizations of the island. By 1938, there were 52 committees of Catholic youth functioning in Cuba that were incorporated into the federation (Fernández Santalices 1998, 24-25). As one of its members declared, "así pudieron crearse iniciativas autónomas de espiritualidad, estudio y acción apostólica que convirtieron la Federación 
en paradigma de apostolado seglar organizado en el sector juvenil-la primera en su género en Cuba (Fernández Santalices 1998, 25).

Another organization that played a key role in Cuban society and politics was the Agrupación Católica Universitaria (ACU). This association was founded by the Jesuit priest Felipe Rey de Castro in 1931. The initial objective of ACU was to establish a continuing relationship between a Catholic educational institution (Belén) and its graduates that attended the secular University of Havana. ACU, however, became much more than that. It developed into a strong young Catholic presence within the university that developed political connotations. It was an elitist group of well-educated and genuinely committed Catholics that strove to recruit influential members with the same characteristics. Numerous ACU members were deeply involved in the revolutionary struggles of 1933 and later in the 1950s (Fernández Santalices 1998, 27; Pérez 1994, 201203).

\section{The Church and the workers}

In 1891, Pope Leo XIII announced in his encyclical Rerum Novarum (On the Condition of Labor) the Church's preoccupation with the situation of the workers in an increasingly industrialized world. He also announced the Church's commitment to the betterment of the workers' conditions. Referring to the responsibility of the employers and the state over labor, he emphasized: "equity therefore commands that public authority show proper concern for the worker so that from what he contributes to the common good he may receive what will enable him, housed, clothed, and secure, to live his life without hardship" (Rerum 51). The pope exhorted those with some responsibility over the workers to develop a series of measures for the workers' betterment. He added 
that the well being of the workers should be a priority for the state and employers alike as it was for the common benefit of society (Rerum 51).

Because of the upheavals of the independence war and the island's colonial status, the Catholic Church did not make workers a priority until several decades later during the Republic. The capitalist economy of Cuba, born with the end of the colony provoked a rapid growth of the working class. The first documented indication of the Church's preoccupation for the workers in Cuba is found in the Boletín in 1911. The periodical mentions a retreat prepared by a priest for a group of workers during a Misión Parroquial in San Antonio de los Baños, on December 12, 1910 (R.D. 1911, 12). From then on, the preoccupation for the Cuban workers became a constant for the Church, as expressed in most pastoral letters published in the Boletín.

In August 1914, Severino Sainz, Ecclesiastic Governor of the diocese of La Habana, called for a meeting with the pastors and religious superiors serving in the diocese, in order to develop pastoral and economic strategies to aid the workers in need. He urged the establishment of organizations in favor of the workers and requested financial cooperation for the creation of a trust fund to benefit that sector of society (Sainz 1914, 19-22).

Towards the end of the meeting the Comité Central de los Obreros was founded. The committee was inaugurated by several men that would be key in the history of the Church in the coming years as well as in the Church's efforts to improve the workers' situation in the island. Among them were the Dominican priest and prior Francisco Vázquez, and the diocesan priest Enrique Pérez Serantes. They donated $\$ 1,500$ to open the trust fund for the workers (Fraga, 1914, 226-227). 
A month later, Sainz issued another letter congratulating the clergy and the lay people for their positive response to the plight $\left(\operatorname{COCC}^{20} 1995,2\right)$. The participants had donated a total of $\$ 2,600$ (Comité 1914,225). Those who could not attend the meeting donated during the following weeks $\$ 3,964$ in Spanish gold, $\$ 103.62$ in Spanish currency, and \$208.59 in U.S. dollars. The money was given to the Comité Central de los Obreros as a contribution of the diocese of La Habana to the trust fund established for the workers' cause (Rodriguez 1914, 212-215).

By December 1914, there was a Comité de Socorro para los Obreros sin trabajo in each parish of La Habana. The committees cooperated economically and spiritually with the less privileged workers. The Boletín published a letter in the name of the benefited workers in which they praised the work of the young priest Pérez Serantes as the director of the central committee. They also congratulated Fr. Vázquez "por la actividad que ha desplegado en su parroquia del Vedado: puede servir de modelo, $y$ acaso señale nuevos rumbos a la acción de la iglesia en La Habana (Variedades 1914, 282-284). In January 1915, a new organization emerged, “Asociación de Obreros Católicos de Cuba, que se propone trabajar por Dios, por la Patria y por la Familia" (Variedades 1915, 22). The association inaugurated a Center for Catholic workers, which functioned as its headquarters as well as for conferences, meetings, and retreats (Variedades 1915, 22).

\section{Academia Católica de Ciencias Sociales and the Workers' Legislation}

The Boletín was right about the "nuevos rumbos" being set by Fr. Vázquez. The Dominican friars had already begun a pastoral focused on the workers' neighborhoods known as El Fanguito and Pan con Timba, in the outskirts of El Vedado, where they later 
established temples dedicated to Jesús Obrero and Santa Rosa de Lima, respectively (Larrúa Guedes 1997, 230-231). They organized and financed workshops where they offered training to unskilled men and women so they could insert themselves into the competitive labor market rapidly growing in Cuba (Eguino 2000).

In 1919, the prior of the Dominican friars, Fr. Francisco Vázquez, and the prior of the Third Order of St. Dominic, Dr. Domingo Villamil, saw the need to integrate the intellectual tradition of the Dominicans with the needs of the time. They were joined in their thought process and enthusiasm by the Cuban jurisconsult Dr. Mariano Aramburo y Machado and the well-known Cuban intellectual José María Chacón y Calvo, both also members of the Third Order of St. Dominic. They developed the framework for what constituted the first Academia Católica de Ciencias Sociales in Cuba (Larrúa Guedes 1998, 445; Eguino 2000).

The Academy was officially inaugurated on October 26, 1919, by Msgr. González Estrada, at the Dominican Priory of San Juan de Letrán in El Vedado (Garrote Amigo $1919,571)$. Among the more than twenty lay and cleric faculty members of the academy was Dr. Manuel Arteaga y Betancourt ${ }^{21}$ (González Bacallao 2000, 22). Since its foundation, until it ceased to exist in the late 1950 s, the academy played a very important role in the education and promotion of the Cuban working class. The members of the academy sponsored public weekly educational conferences in San Juan de Letrán targeting the workers as its main audience (Larrúa Guedes 1997, 226).

In order to disseminate important information they founded the trimestral periodical La Antillana. This journal contained informative, scientific, social, and legal articles promoting the education of the labor force, as well as the obligation of the 
government to rethink its legal stance with regards to the workers and needy sectors of society. La Antillana gained great popularity among Cuban workers and intellectuals. Some of the articles such as "Viviendas para obreros" by Juan Isern, and " $\mathrm{La}$ agremiación obrera" by Fr. Francisco Vázquez, published by the journal became the foundation for several projects later developed at the academy (Larrúa Guedes 1998, 451).

The founders of the Academia did not think it was sufficient to teach, write, and publish. Following the academy mentors' traditions, they wanted their work to be tangible and consequential. The same year, 1919, lead by Dr. Mariano Aramburo, and urged by the sociopolitical situation of the island, involving the working class, the members of the academy developed the Proyecto de Código del Trabajo (PCT hereafter) (Larrúa Guedes 1998, 451).

The project for workers' legislation was introduced in the Cuban senate on July 20, 1920, and a copy was sent to the President of the House of Representatives. In the presentation speech, Dr. Aramburo mentioned that a project of that kind "no se ha llevado a cabo en ninguna parte del mundo, siendo Cuba la primera nación en realizarla por el esfuerzo de la Academia (Aramburo y Machado 1920, 3-4).

The legislation provided for the establishment of Bolsas de Trabajo, as a way of satisfying the increasing demand for employment, and to facilitate the relationship between employers and employees. They would promote industrial development as well as an increase in overall productivity. The PCT also recommended the creation of Tribunales de Arbitraje to solve any existing disagreements between employers and employees (Aramburo y Machado 1920, 12, 13). 
The developers of the PCT recommended in Title IV bringing the workers together into gremios (unions) in order to improve their relationship with their employers, as well as creating a mechanism to streamline the workers' demands (Aramburo y Machado 1920, 16). Title X of the PCT established the right of workers to go on strike, and explained the difference between licit and illicit strikes (Aramburo y Machado 1920, 38). The legislation required employers to guarantee the preservation of salaries, a weekly time off, and a fixed number of eight working hours. It also required the establishment of workers' insurance in order to secure the continuous flow of income for the support of the workers and their families in case of accident, death, handicap, or illness (Aramburo y Machado 1920, 28-35).

The legislation established punitive measures for workers and employers in case of any violation of the established rules and regulations. It even set the percentage (75\%) of the salary to be paid to the workers in case of a justified inability to work, ensuring the economic survival of those who depended on the employee (Aramburo y Machado 1920, 28-35).

The founders of the Academy undertook the development of other legislative projects, intended to complement the PCT. They were presented at diverse conferences and published in La Antillana. Some of those projects were the Proyecto de Leyes para la Protección de Mujeres, Proyecto para Viviendas Económicas para los Obreros, Proyecto para Reformas Económicas, and Proyecto para Reformas Politicas. (Larrúa Guedes 1998, 456-458).

Although these projects were never legalized because they required considerable funding and a thorough socioeconomic and political reform at the national level, they 
were not a waste of time. They reveal the degree of concern of these Cuban Catholic intellectuals for the socioeconomic marginalized and for the improvement of the nation. The importance of those projects, however, goes beyond the demonstration of the personal qualities and qualifications of the developers. Their significance rests in their potential to influence the Cuban legislation.

\section{The Sociopolitical Period (1940-1959)}

The Constitution of 1940 has been considered, among other superlatives, as a "crisol de Cubania y fragua de democracia" (Carbonell Cortina 2001, 13) and as "la prueba más eficaz de la madurez del pueblo cubano" (Carbonell Cortina 2001, 55). With 286 articles, 41 transitional dispositions, and 1 final disposition, the constitution competently addressed and proposed legal solutions to the socioeconomic and political problems afflicting Cuba (Martinez Sánchez 1975, 586). The new laws, however, did not change the status of the Catholic Church in Cuba.

The constitution was a lay text, pluralistically developed with the purpose of regulating a pluralistic society (Céspedes García-Menocal 1996, 15), and as such it did not differ much from the previous one. Consequently, the constitution implied, in legalistic language, what had been decreed in the preceding document of 1901: that the Catholic Church was one more religious organization within Cuban society.

Religion, nonetheless, was not absent from the constitutional debates. The articles containing any reference to religion were fervently opposed and criticized by Blas Roca, Juan Marinello, and Salvador Agüero, all delegates from the Communist Party. They basically argued that including religious terms in the constitution empowered religious institutions. In contrast, those articles were defended by Carlos Prío, Miguel 
Coyula, and Emilio Nuñez, all from different political parties. They argued that if the constitution was to be a democratic document, it had to be inclusive of all sectors of the nation. They added that religiosity, particularly Christianity, was a cherished value of the Cuban people and an intrinsic part of their traditions (Carbonell Cortina 2001, 65-73; 193-208; 258-275).

This time the Church, which had gained in organization, numbers, and influence, was not as silent as it had been in 1901 . Indeed, the hierarchy voiced its stance, representing the Catholic constituency. In a public letter addressed to the constitutional assembly the Cuban bishops proposed five points to the delegates, which they wanted to be sanctioned in the constitution, as they were of transcendental importance for religious people (COCC 1995, 26).

In their first point, they asked the delegates to include the right to freedom of education. The bishops argued that it was a right of the parents to decide the kind of education they wanted for their children. The Cuban hierarchy also stated that private education was beneficial to the state's economy, as the state could not provide education for all without incurring in onerous taxes on the citizenry (COCC 1995, 26, 27).

A second point, related to the first one, was the inclusion of religious education in the public school system, always respecting the individuals' choice of not receiving it. The bishops explained that they were not advocating for Catholic indoctrination, or for favoritism over any particular religious sect. They were trying to safeguard and promote the spiritual and intellectual virtues and progress of the nation and all its religious components. They cited José Martí stating that "sólo las virtudes producen en los pueblos un bienestar constante" (COCC 1995, 28). 
The third and fourth points suggested by the Cuban bishops were regarding matrimony. Point three asked for the protection of matrimony as an institution, and point four requested that religious marriages be recognized as legal acts. They wanted the constitution to recognize the indissolubility of matrimony. Citing research done in the United States, they added that divorce contributed to the deformation of human demeanor. The bishops included in their argument that matrimony constituted a Sacrament for Catholics, and that the absence of it was detrimental to the Christian values of their offspring (COCC 1995, 29-30).

Their fifth and final point requested that the assembly develop a constitution beneficial to the marginalized working sector. The undersigning bishops reminded the legislators that the global turmoil they were currently living in was due to the imbalance between labor and capital. The bishops brought to the legislators' attention the papal encyclicals Rerum Novarum and Quadragésimo Anno (Fortieth Anniversary), issued by Leo XIII and Pius XI, respectively. Both documents addressed the impoverished living conditions of the vast majority of the working class, as well as their legal vulnerability. Both decrees also recommended those in power to search for measures to protect the proletariat (COCC 1995, 30-31).

At the same time the Cuban Catholic hierarchy counted with the support of the Catholic constituency. As expressed by Emilio Nuñez at the constitutional debate over Article 35 , they had received a petition signed by more than fifty thousand citizens supporting their religious rights. Furthermore, it can be inferred from Nuñez's comment $^{22}$ that not decreeing the freedom of religious beliefs and practices might have resulted in a religious war (Carbonell Cortina 2001, 202). 
In addition, the Catholic periodical Semanario Católico, before, during, and after the constitutional assembly, published articles discussing the social issues being considered by the legislators. It reminded the Cuban Catholics of the importance of the constitution as well as of their participation in the political life of the nation (Fernández Santalices 1998, 38). The periodical voiced the right of the Catholics to request religious education and "lo que estime conveniente, y si eso equivale a crear un problema a la nación, entonces que nos amputen la libertad de la persona humana y que nos secuestren la democracia" (Fernández Santalices 1998, 39).

The Cuban Catholic organizations lead by Msgr. Arteaga, called for a public demonstration of Catholic political participation in La Habana. On February 24, 1940, more than twenty thousand people met in the areas surrounding the national capitol where the constitutional assembly was gathered. The meeting was called "Pro-Patria $y$ reafirmación católica". The Catholic demonstration was endorsed by more than twentyfive thousand signatures of individuals, organizations, and political parties. The interventions of different religious and political leaders were transmitted through the radio, and covered by most national press (Fernández Santalices 1998, 40-42). The newspaper El País described it as "un homenaje a la patria cubana y a los ideales católicos muy arraigados en el seno de nuestra sociedad" (Fernández Santalices 1998, 41).

The resulting constitution, as it had happened in 1901, included the invocation to God in the preamble. It maintained the separation of Church and state, and decreed that public education remained secular and controlled by the state. The constitution also 
allowed for the establishment of private educational institutions, regardless of their religious affiliation (Constitution 1940, Preamble; Arts. 35,55).

In a letter published by Msgr. Arteaga, who had become the Vicar of the diocese of La Habana upon the death of bishop Ruiz, he made public his thanksgiving prayers for the resulting constitution. He also urged the Cuban population to participate in any electoral process to take place in the country. He reminded the readers that voting was a patriotic duty of Cuban Catholics (Arteaga y Betancourt 1940, 39-40).

Arteaga, however, did not recognize, at least publicly, the resemblance between some articles of the Constitution and the projects previously developed by the Catholic Academy for Social Sciences. It is possible that Arteaga, who was still a member of the academy, did not mention the projects as a precautionary strategy. Mentioning the influence in the Constitution of a Church-developed project could have caused the critics of religion and the anticlericals to oppose its inclusion in the constitution. That would have prevented any legal benefits the legislation might have brought to the marginalized. Or perhaps Arteaga did not remember the projects.

Whichever the case, the possible influence of the projects developed years earlier by Aramburo, Chacón, Arteaga, and the Dominicans, in favor of the marginalized was never acknowledged ${ }^{23}$. A superficial comparison between the Academy projects and the articles of the constitution dealing with issues such as the formation of workers' unions, the establishment of affordable housing for the working class, and the workers' insurance, reveals striking similarities.

For example, Article 65 of the constitution corresponds to Articles 74-85 of the PCT. They refer to the need for the implementation of workers insurance. The 
constitution calls for the establishment of a Banco de Seguros Sociales, and the PCT for a Caja Nacional de Seguro Obrero. The purpose of the Banco or Caja was to guarantee the payment of indemnifications controlled by the state. Additionally, Article 69 of the Constitution matches Articles 21-42 of the PCT. They institute the right to form unions or syndicates. Article 72 of the Constitution is the equivalent to the Projecto para Viviendas para Obreros presented by the Academy in 1921 (Constitution 1940, Arts. 65, 69, 72; Aramburo y Machado 1920, 28-29, 16-20; Isern 1921, 226-289). These are just a few of many similarities.

The possible connection between the Catholic Academy for Social Sciences and the constitutional assembly appears to be through an individual common to the academy and the constitutional assembly. Upon the retirement of Dr. Mariano Aramburo, Dean of the Catholic Academy for Social Sciences, Dr. Manuel Dorta Duque took over the direction of the Academy (González Bacallao 2000, 22).

Dorta Duque had been present and given lectures at several of the conferences organized by the Academy (Gacetilla 1921, 51-52). He was a practicing Catholic, a professor and Dean of the Law School at the University of La Habana, a legal scholar, and, in 1939, a delegate to the constitutional convention (Carbonell Cortina 2001, 354). It is not impossible that he might have brought the PCT, and the other projects of the academy to the attention of the constitutional assembly. In any case, the Constitution of 1940, "one of the most serious political achievements of the Cubans" (Thomas 1998, 719) was also an accomplishment for the Church. It was the first significant public intervention of the religious personnel and the laity in unison in the political affairs of the nation during the Republic. 


\section{Reorganizing the laity into Catholic Action}

Ever since the establishment of the first lay organizations in the island, the Cuban laity had given countless demonstrations of its commitment to the evangelization of the island, and of its adherence to the Catholic hierarchy. They had expanded into numerous organizations working in many and diverse sectors of Cuban society. The diversity and number of those groups, however, was not in consonance with the organizational and hierarchical tradition of the Church.

The intrinsic corporatism of the Catholic Church in Cuba, as a part of an international state (the Vatican) had been reinforced by centuries of Spanish colonialism. The corporatist paradigm endorsed the notion of law, order, stability, and elite leadership through a centralized bureaucratic authority [the bishops] in charge of ruling over and coordinating with, sectoral groups hierarchically and organically integrated (Fernández 2000, 27).

Besides keeping a tighter control over their subordinates, the Cuban hierarchy wanted to provide the Cuban laity with a legal status within the universal Church to which they belonged. In 1938, the bishops had called for the unification of the Cuban Catholic laity within one international organization, Catholic Action. It was a response to the need for the evangelization of the island, aggravated by the lack of religious personnel (Zubizarreta et al. 1939, 3-15). Due to bureaucratic delays, and to the death of the bishop of La Habana, Msgr. Ruiz, and his replacement with Arteaga as Vicar, the official foundation of Catholic Action did not take place until 1941 (Fernández Santalices 1998, 30). 
Catholic Action was divided into four main branches: Federación de la Juventud Católica (F.J.C.), Asociación de Hombres Católicos (A.N.H.C.), Liga de Damas Católicas (L.D.C.), and Liga de la Juventud Católica Femenina (L.F.J.C.). They were all under the Junta Nacional that controlled the Juntas Diocesanas, which in turn commanded the Juntas Parroquiales (Acción Católica 1946, 7-8).

Each branch was given a mission within the new organization. The F.J.C. received the mission of evangelizing men in the cities and the countryside. They were also in charge of promoting attendance to mass on Sundays and of safeguarding Christian morals in public spectacles. The members of A.N.H.C. were to promote and defend the emergent Christian Social Democratic movement, as well as advocating for the working class and their well-being. They were also responsible for Christian morals being kept in Catholic schools (Acción Católica 1946, 7-8).

The female organizations were to contribute to the evangelization of the island according to the social roles of the time. L.D.C. members were trusted with instilling Christian values at home, teaching catechism to children, and promoting and protecting religious vocations. Young women, members of L.F.J.C., needed to cooperate with the L.D.C. with regards to religious vocations. They were also responsible for combating paganism and immorality in the fashion industry (Acción Católica 1946, 7-8).

Some other transformations followed, and other organizations were created; among them was Juventud Obrera Católica, in 1947. They had the mission of promoting Catholicism within the members' place of work. This organization had the characteristic of remaining independent from Catholic Action. Its members wanted to avoid the restrictions imposed by corporatism. They needed autonomy in order to better perform 
their duties at factories and within workers unions, and they were allowed to do so (Fernández Santalices 1998, 29).

The new organization of the laity provided more efficient channels of communication between the clergy and the laypeople, and vice versa. It was also a more effective system to coordinate the massive evangelization of Cuba that the Church had been planning to launch with the motto of "Piedad, estudio y acción ... por Dios y por la Patria" (Pérez Serantes 1942, 63-68).

\section{The first cardinal}

The growth of the Church in Cuba since its independence from the Patronato was significant. The increase in the number of educational and health related institutions, in the number of religious personnel, and the augment of the committed laity in Cuba was known to Rome. In February 1944, the official newspaper of the Vatican, L'Obsservatore Romano, published an article praising the efforts of the Catholic Church in Cuba in providing social services. It also congratulated the Cuban Church and its hierarchy for its organizational skills (L'Obsservatore 1944, 388-390).

The same article published some statistics of Catholic education in Cuba at the time. There were 105 schools congregated in the Confederación de Colegios Católicos Cubanos, with a total of 24,693 students. Out of those, $6,610(26.8 \%)$ received free education, 7,418 (30\%) paid a minimum contribution ${ }^{24}$, and 10,665 (43.2\%) paid full tuition $^{25}$. The students were taught by 1,316 lay and religious professors ( $L$ 'Obsservatore 1944, 388-390).

Rome wanted to recognize the efforts of the Cuban Church. On December 24, 1945, Pope Pius XII presented the Cuban Church and nation with the highest honor the 
Roman Catholic Church confers, a Prince of the Church ${ }^{26}$. The title was bestowed on the archbishop of La Habana, Msgr. Manuel Arteaga y Betancourt (Editorial 1946, 1-2). Of the five cardinals elected for the Church in Latin America, the Cuban archbishop had been selected as the first cardinal for Cuba, Central America, and Mexico (Céspedes García-Menocal 1996, 23).

A high-ranking religious official in Rome offered some reasons why the Church in Cuba had been selected for such an honor. He said that no other Church in the Caribbean and the Mexico/Central America area had proportionally grown at the pace that the Catholic Church had grown in Cuba. No other Church in the region had a laity and a native clergy with the level and quality of education than the Church in Cuba. No other Church in the area had the facilities for the establishment and support of religious orders and congregations as the Church in Cuba (Céspedes García-Menocal 1996, 24).

When asked why Arteaga had been chosen, the same religious personality answered: "por sus cualidades personales, todavía ${ }^{27}$ brillantes". He added that Arteaga was in part responsible for the prosperity of the Church in the island; therefore it was convenient to support the Church in Cuba, and to support him (Céspedes García-Menocal 1996,). At the time of his appointment, Msgr. Arteaga had been the General Vicar of the diocese of La Habana for over 25 years, and archbishop for four. He had also served as apostolic administrator of Pinar del Río for the same period (Editorial 1942, 1-2).

A member of a prominent Cuban family of proven patriotism, Arteaga had received an outstanding education in Cuba and later in Venezuela ${ }^{28}$, where he was ordained a priest. Since his return to Cuba in 1911 Arteaga began working for the development of the Church on the island and for the well being of the nation. $\mathrm{He}$ soon 
became an outstanding Church leader with excellent political skills. In 1912, already a priest, he became a congressional representative for the province of Camagüey (Céspedes García-Menocal 1996, 4-5,7-10).

He founded and directed several newspapers. Among them was Religión y Patria, where he constantly voiced his sociopolitical and religious ideals. In 1915, while bishop González was looking for a General Vicar for the diocese of La Habana, he listened to the advice of an old Cuban priest: "No busque más, Excelencia, he encontrado una joya escondida en Camagüey". Arteaga was transferred to La Habana, where he immediately became involved in the emerging lay movement and the social work of the Church (Céspedes García-Menocal 1996, 4-5,7-10).

Upon taking over the direction of the archdiocese of La Habana, Arteaga decided to make public his intention of "patriotizar" the Church. He tried to celebrate the Church's congresses and major feasts to coincide with important patriotic dates. For instance, commemorating the beginning of the independence war of 1895, Arteaga inaugurated the Archdiocesan Museum on February 24, 1941. He placed the first stone for the construction of the new seminary, El Buen Pastor, on October 10, 1941, in remembrance of the date, when, in 1868, Carlos Manuel De Céspedes freed his slaves, and began the war of independence (Céspedes García-Menocal 1996, 16).

His ceremony of consecration as archbishop took place on February 24, 1942 (Lebroc Martinez 1985, 48). He officially declared February 24 as "Dia de acción de gracias y de oraciones a Dios Nuestro Señor, por los beneficios recibidos y para impetrar sus bendiciones sobre nuestra Patria". He urged the laity to participate in mass 
on that day and to ask Our Lady of Charity, patroness of $\mathrm{Cuba}^{29}$, to intercede for the nation (Arteaga y Betancourt 1945, 4).

Arteaga was supported by the other bishops in his attempt. In May 1951 they called for a nationwide procession with the Virgen de La Caridad. The procession was to begin in El Cobre and end in La Habana on May 20, 1952 to commemorate the fiftieth anniversary of the establishment of the Republic. The bishops stated in the convocation that they wanted the procession to end with "un acto tan grandioso como lo que es el amor que a Dios y a la Patria profesamos nosotros, y deben profesar todos los cubanos" (Arteaga y Betancourt 1951, 237).

The growth and development of the Catholic Church continued under Arteaga. Several Catholic congresses, even some of international resonance, took place in Cuba, such as de Second International Congress of Catholic Social Studies, the Segunda Semana Interamericana de Acción Católica, and the First Regional Congress of the Caribbean and Central America (Fernández Santalices 2001, 108, 110, 112).

The number of children attending catechism in La Habana rose from 45,800 in 1943 , to 64,728 in 1945 . Statistics published for the same years also show an increase in the number of students in Catholic schools from 24,500 to 28,576, respectively (Movimiento Catequístico 1946, 31).

In 1946 Arteaga inaugurated the Catholic University of Santo Tomás de Villanueva, founded by the North American Augustinians under the leadership of Fr. Spirale. Arteaga also promoted and funded the establishment of schools in the rural areas of the diocese, as well as the construction and reconstruction of temples and schools in the growing suburban areas. He founded a center for spiritual retreats and restored the 
old seminary. He was the first Church leader to encourage the Catholic clergy and laity to openly participate in the political processes of the nation, as well as to voice their ideals utilizing the newly available mass media. Arteaga became a very public figure through his attendance at the inauguration of buildings, factories, schools, and hospitals (Céspedes García-Menocal 1996, 25).

Another area that constantly worried Arteaga was the historical shortage of priests in Cuba. He promoted vocations from all sectors of society, and when the number of vocations began rising ${ }^{30}$, Arteaga ordered the construction of a new seminary, El Buen Pastor, in Arroyo Arenas in the outskirts of Havana. Arteaga was also known as a man who believed in racial equality, and he demonstrated it. Upon his consecration as archbishop he called for the first group of men to be ordained. The first one, as promised by Arteaga, was Armando Arencibia, the first black man to be ordained in Cuba (Céspedes García-Menocal 1996, 16,19; Eguino 2000).

In 1951 Arteaga celebrated the $25^{\text {th }}$ anniversary of the establishment of the Misiones Parroquiales. To that date, the Ecclesiastic Province of La Habana had undertaken 2,367 Misiones Parroquiales (Chaurrondo 1951, 177). Although no total numbers were published for the twenty-fifth anniversary, the Misión Parroquial of San Antonio de Los Baños of 1951, for example, offers stunning figures, when compared to earlier ones. In the five days the Misión lasted, 2,780 people went to confession, 2,704 received First Communion, 840 adults were baptized, and 700 matrimonies were legalized. The Misión was extended to the surrounding factories where a Via Crucis was organized with the participation of over 5000 people (Grandiosa Mision 1951, 180). 
The Cuban Cardinal, as a representative of the Pope, participated in various international congresses in Latin America. He also received several recognitions for his pastoral work. The University of Tampa conferred him the Doctorate Honoris Causa in Law, the city of Camagüey named him its Eminent Son, and the Cuban government bestowed upon him its highest honor, the Orden de Carlos Manuel De Céspedes (Testé 1969, 296; Arteaga y Betancourt 1950, 85).

\section{The end of the Republic ${ }^{31}$, and of the splendor of the Church (1962)}

The 1950s in Cuba were marked by socioeconomic and political contradictions. While socioeconomically the island ranked among the top five countries in Latin America on issues such as urbanization, literacy, per capita income, infant mortality, and life expectancy, the political disorder was rampant. The three post-1940 administrations failed to abide by the constitutional order (Pérez-Stable 1999, 5,9).

Fulgencio Batista, who had won the elections of 1940 , served as president until 1944. He was followed by Ramón Grau San Martín, who was succeeded by Carlos Prío Socarrás in 1948. Then in 1952, Batista came back and, supported by some sectors of the army, seized power through a coup d'état, suspended the 1940 Constitution, and dissolved the congress (Costa 1998, 266-394).

In 1953, Fidel Castro organized a group of 165 people and attacked the Moncada barracks in Santiago de Cuba. The attack was a fiasco, leaving several dead, and others arrested. Among the ones detained was Castro who was sentenced to jail (Pérez-Stable 199, 53). The archbishop of Santiago, Msgr. Pérez Serantes, issued a letter three days later, on July 29, expressing his condolences to the families of the ones killed and to the 
people in general. He asked for the prompt restoration of peace, and added that the authorities had agreed to cooperate towards the desired peace (COCC 1995, 34-35).

The same bishop urged by Cardinal Arteaga, intervened with governmental officials for the liberation of the arrestees (Céspedes 1996, 27). The bishop was granted the petition and also the guarantee that the prisoners would not be tortured or murdered (COCC 1995, 36-37). Instead the detainees were sent to exile.

In 1956 Fidel Castro, along with approximately 80 insurgents returned to Cuba, to fight Batista's dictatorship. He landed in Oriente, but his group was crushed by the army, and Castro escaped into the mountains, where he organized the Movimiento 26 de Julio, so called to commemorate the unsuccessful 1953 uprising. It was the beginning of the guerrilla war that took him to power (Costa 1998, 266-394).

Numerous members and supporters of the Movimiento 26 de Julio as well as of the guerrilla in general were practicing Catholics, members of organizations such Juventud Obrera Católica, Agrupación Católica Universitaria, and other branches of Catholic Action. There were 11 priests accompanying Castro and his guerrilla band, one of them, Fr. Sardiñas even reached the rank of commander and later became part of the revolutionary government (Meier et al. 1995, 340; Fernández Santalices 1998, 66-71; Fernández 2000, 72).

The years of Batista's dictatorship filled with sociopolitical unrest and the constant confrontation between governmental and Castro's group, were a time of extreme tension for the Catholic Church. The clergy was divided into three main groups: those who supported the insurgent movement led by Castro because of the social changes it promised; those who opposed it because it reminded them of the disastrous effects the 
Spanish Civil War had had on that country's religious institutions; and those in a third position that were against both Castro's movement and Batista's government because the conflict was causing great bloodshed and destruction. Among those who were in the third position were Cardinal Arteaga and Msgr. Pérez Serantes (the latter increasingly leaning towards Castro's ideals). Both archbishops raised their voice many times from the pulpit advocating peace and reconciliation (Meier et al. 1995, 340-350; DREC 1962, 3; Fernández 2000, 72).

In 1958 all the Cuban bishops signed a letter titled "En Favor de la Paz" asking all parties in the conflict to put an end to the violence and to search for "soluciones eficaces que puedan traer de nuevo a nuestra Patria la paz material y moral que tanta falta le hace" (COCC 1995, 40-41). Arteaga was even part of a Concord Committee which tried to reconcile the antagonistic parties and put an end to the conflict (COCC 1995, 42). The peace efforts of the Catholic hierarchy, however, did not succeed.

After two years of guerrilla war Castro, with considerable popular support, called for a general revolt in 1958, which among other causes forced Batista to flee the country on New Year's Eve. Castro arrived in La Habana a week later, after naming Dr. Manuel Urrutia as president of the revolutionary government on January 4. The Cuban people gladly accepted Batista's exit and welcomed the new government filled with expectations (Pérez-Stable 1999, 61)

The triumph of Castro's revolution was seen as a relief to the brutality and corruption of Batista's regime. Many members of the Catholic Church applauded his arrival. Among them was bishop Pérez Serantes who even wrote an article in the Franciscan newspaper La Quincena. He expressed that because of Castro's commitment 
and victory, supported by a large segment of the population "the Divine Providence has written on Cuba's sky the word TRIUMPH" (Fernández 2000, 72).

The euphoria was apparently justified. Castro and many of his followers were declared Catholics and had been educated in Catholic schools and universities. Castro, for instance, had graduated from one of the most prestigious catholic schools of the island, Belén, under the guidance of the Jesuits (Kirk 1989a, 65; Céspedes GarcíaMenocal 2001). Upon his arrival in La Habana Castro even kissed the flag of Belén, his Alma Mater. Among other things, he promised the Cuban people that he would introduce religious education into the national school system. In 1960, however, less than two years after the euphoria, the relationship between the Church and the new government was heading to an inevitable break (Kirk 1989a, 65).

There were several issues that marked the split between the Church and Castro's government. The first was the radical reforms immediately started by Castro, which affected land, urban properties, and education. Second was his almost immediate alliance with the Soviet Union, which was seen as a major enemy of the Church for its communist atheist philosophy. The third problem, what enraged Msgr. Pérez Serantes the most, was the execution of close to 400 "war criminals" for whom the bishop of Santiago had pleaded for clemency in the same manner he had done for Castro years before (Kirk 1989a, 65-67).

The tensions between the Church and the government had earlier roots. On January 10,1959 , only two days after Castro's arrival in Havana, the invocation to God was eliminated from the swearing ceremonies of judicial functionaries. On February 7 , 
God's name and invocation were removed from the preamble to the Cuban constitution (DREC 1962, 5-7).

In addition, the arbitrary application of the Agrarian Reform promulgated by the new government, was criticized by Msgr. Pérez Serantes and other bishops (COCC 1995, 80-86). The Cuban hierarchy had earlier supported said reform, even though it represented along with the Urban Reform laws, the loss of a large sum of money in properties for the Church. At that point, many Catholics who had supported Castro against Batista began to distance themselves from Castro's ideas and from his government (DREC 1962, 5-7).

The Catholic hierarchy was not silent about the aggressions and the reforms rapidly undertaken by the government, especially those on education. Between February 13, 1959, and February 11, 1961, the Cuban bishops, individually and/or jointly, published 23 letters openly protesting and criticizing the actions and attitude of the Cuban government (COCC 1995, 64-170).

The letters began with one criticizing the educational reform, which severely threatened the Church, and ended with one in which Pérez Serantes clarified to a local newspaper that he was not against the peasants as he had been born and raised as one, but against communism. In the letters, the Cuban bishops asserted their commitment to support those governmental measures trying to eliminate hunger, misery, and injustice. They also reinstated their opposition to those laws that would try to deprive any person of their human rights (COCC 1995, 64-170).

In the middle of the turbulent relationship between the Catholic Church and the government, the Church organized what became its last public massive religious act, the 
Catholic National Congress. The closing ceremonial act took place at the Plaza Cívica. The exact number of participants was never established, but some set the number at over one million. It was the largest gathering of Catholics ever to take place in the island, and even Castro and several members of its cabinet attended the mass, which took place at 2:00 am. The original image of the Virgin of Charity was brought from El Cobre to preside over the service. To avoid confrontations, it was decided that only Pope John XXIII would speak to the masses (from Rome). The Pope called for Christian reconciliation to build a better society (Belda Mas 1999, 139). "El Congreso Católico Nacional de 1959 fue como el último gran gesto, el postrer esfuerzo de esa generación por alcanzar el bien común en una Cuba "creyente y dichosa" (Fernández Santalices 1998, 14-16).

The hostility between the government and the Church obliterated any efforts for the "bien comun", and the attacks from governmental leaders against the Church for its opposition to the direction the government was taking began to escalate in number and frequency. The attacks increased with Castro's pronunciation on December 26, 1960 that "to be an anti-communist is to be a counterrevolutionary" (Clark 1986, 8). Consequently, most members of the Catholic Church, due to their outspoken anticommunism, were marked as enemies of the revolution. The verbal attacks turned into physical aggressions, especially after the Bay of Pigs incident, in which several priests accompanied a group of exiles in a failed attack against Castro's government (Fernández Santalices 2001, 123124). Several Catholic temples were desecrated and occupied by soldiers. Many Catholics were beaten and arrested along with their pastors even during religious celebrations (Fernández Santalices 2001, 123-124; DREC 1962, 3-9, Fr. 2001). 
Several more violent incidents, prohibitions of services, arrests, expulsion of clergy, and even killing of lay people took place. One of those incidents severely changed the history of the Catholic Church in Cuba and seriously diminished the Church's role within Cuban society. It happened in 1961, during the celebration of the feast of Our Lady of Charity. Msgr. Boza Masvidal, Auxiliary Bishop of La Habana, and pastor of the parish of Our Lady of Charity, was in charge of the celebration. Due to new governmental regulations controlling public religious gatherings, he had to request permission from the authorities to celebrate the procession. Boza followed the rules and obtained the permit (Clark 1986, 10-12; DREC 1962, 25-26; Fr. 2001, Belda Mas 1999, 145).

The procession had been scheduled for Sunday, September 10, at 5:00 pm. Early in the morning of September 10, governmental officials informed Msgr. Boza that the procession could take place only if it was done before 9:00 am. The bishop sent the message out to the parishioners in order not to be confrontational, because he had already been detained once by the government (Fernández Santalices 2001, 23). He even removed the image of the Virgin of Charity that was to be used for the procession (Clark 1986, 10-12; DREC 1962, 25-26; Fr. 2001; Belda Mas 1999, 145).

People began arriving at the pre-arranged time and were infuriated when they found out about the suspension. They decided to go on with the procession led by an image of the Virgin of Charity brought by one of the participants, Arnaldo Socorro, a member of the Juventud Obrera Católica, who lived nearby. He was carried on the shoulders of some of the marchers, and the procession, which had began as a religious celebration, turned into a protest against the regime. The police tried to stop the 
procession/demonstration, but were not successful. Someone opened fire on the participants. Arnaldo Socorro was killed and many others were wounded (Clark 1986, 10-12; DREC 1962, 25-26; Fr. 2001; Belda Mas 1999, 145).

After the incident, the government fabricated many contradictory stories. One story said that the protest had been organized by the CIA and by counterrevolutionary elements. Another version accused the Catholic hierarchy of killing Socorro. The police wanted to take the body of the young man who was only 18 , to bury him with honors as a martyr of the revolution, but the parents did not allow them to do so. A priest from the Church of Our Lady of Charity was charged with the murder, even though it was known that during the demonstration he was at Isla de Pinos. He, along with many lay people, was sentenced to serve time in jail (Clark 1986, 10-12; DREC 1962, 25-26; Fr. 2001; Belda Mas 1999, 145).

Msgr. Boza Masvidal was arrested. On September 17, 1961, Boza, along with 131 priests were taken forcibly and publicly to the Spanish ship Covadonga which was preparing to depart and was already loaded with other religious personnel (Fernández Santalices 2001,124$)$. The majority of the clergy and nuns were taken without being allowed to retrieve their personal belongings and documentation. Some were even taken to the ship wearing their pajamas. The Covadonga left Cuba on that same date; the majority of those taken were not allowed to return (Eguino 2000, Fr. 2001).

The expropriation laws of 1961-62 seriously reversed the path of economic and personnel prosperity of the Catholic Church in Cuba during the Republic ${ }^{32}$. The nationalization laws decreed by Castro's government dispossessed the Church of all its educational institutions and removed the remaining religious personnel from the 
hospitals. After the institutions were expropriated, the superiors of orders and congregations working in Cuba, fearing a similar situation to the Spanish civil war of 1936 , ordered the remaining young personnel to leave the country. Only the oldest remained (Belda Mas 1999, 150; Eguino 2000; Fr. 2001). In 1962, Cuba was left with six bishops, 123 priests, and approximately 200 nuns to serve close to seven million people $^{33}$ (DREC 1962, 10-12).

The only health related institutions that remained functioning under religious supervision and personnel, minimally subsidized by the government, were the San Lázaro leprosarium and the Hogar la Edad de Oro (for mentally retarded children), both properties of the Daughters of Charity of St. Vincent of Paul, and the Asilo Santovenia (for the elderly) that belonged to the Hermanas de los Ancianos Desamparados. Both congregations were allowed to maintain those institutions due to the personal relationship of some of the nuns with some members of the Revolutionary government (Eguino 2000; Fernández 2002; Fr. 2001).

\section{Notes}

${ }^{1}$ Notion referring to the work of Jorge Dominguez (1989), discussed in the introduction.

${ }^{2}$ Economic unbalances of the diocese's treasure, intrigues, and wrongdoings of some priests resulted in Msgr. González Estrada's recall by Rome in 1924. The following year he resigned to his position as bishop of La Habana. Although Rome asked him to remain at the Holly See and made him Archbishop of Atila (an honorary title), he asked the Pope to send him back to his beloved island. He moved to a house near a parish, popularly known as Los Quema'os, in a workers neighborhood in Marianao. A few years later, those who had really been involved in the misconduct for which Msgr. González Estrada had resigned were discovered and punished. Rome tried to reinstate the humble bishop; however he decided not to accept and remained it the same house until his death in 1937 (Leiseca 1938, 222; Eguino 2000). 
${ }^{3}$ A Royal Decree issued by Queen Isabel II reinstated some religious orders in Cuba. Paragraph three refers to the reestablishment of the Jesuits and the creation of the Real Colegio de Belén (Fernández Soneira 1997, 77)

${ }^{4}$ This is only a small list of the institutions opened by the Church focusing on social services. See also Appendix 1 of this thesis for a list of the schools, universities, and technical institutes, opened by the Church during the Republic.

${ }^{5}$ At that time it was known as Boletin Eclesiástico.

${ }^{6}$ It ceased its publication in 1961, with the nationalization undertaken by the current government of Fidel Castro.

${ }^{7}$ This information comes from the research undertaken for this work during the months of December 2001 and January 2002. That research implied the meticulous revision of all the volumes available at La Parroquia del Sagrado Corazón de Jesús del Vedado and the convent and parish of Santo Domingo de Guzmán and Juan de Letrán, in El Vedado, La Habana. The author of this study holds photocopies of all the articles cited.

${ }^{8}$ See endnote 7.

${ }^{9}$ The active role of laypersons within the Catholic Church in Cuba will be redefined later with the foundation of Acción Católica and its branches.

${ }^{10}$ Due to the large number of orders and congregations established in Cuba and the numerous educational and healthcare institutions founded by them, not all can be documented. A few have been chosen, as representatives of the work undertaken in Cuba by the Catholic Church during the Republic. Of those selected, one was founded by a Cuban, the Oblate Sisters of Providence, one founded for Cuba, Hermanas del Amor de Dios, and a third one, the Order of Preachers (Dominicans) that, even though was not founded in, or for Cuba, or by a Cuban, historically contributed to the education of Cubans at all levels and some of its members were partially responsible for the foundation of the Catholic Academy for Social Sciences soon to be introduced.

${ }^{11}$ Mainly from the Dominican Republic and Haiti (Fernández Soneira 1997, 380).

${ }^{12}$ It most be noted that at the time the congregation was founded 1829 , the education of blacks was against the laws in the United States (Fernández Soneira 1997, 380-390).

${ }^{13}$ They opened schools in five of the six Cuban provinces at the time: El Vedado and Marianao (La Habana), Cárdenas (Matanzas), Santa Clara (Las Villas), Camagüey (Camagüey), and Santiago de Cuba (Oriente) (Fernández Soneira 1997, 382-383). 
14 Although the constitution sanctioned that the government would not subsidize the Church's endeavors, personal relationships between governmental and Church officials circumvented the rules (see Fernández 2000, work cited in the introduction).

${ }^{15}$ They opened schools and shelters in Guanabacoa, Palatino, La Vibora, San José de las Lajas, Campo Florido, and El Cotorro (La Habana); in Remedios, Fomentos, 3 in Santa Clara, Cumanayagua, and Ranchuelo (Las Villas); Colón (Matanzas); Central Francisco, Lugareño, and Santa Cruz del Sur (Camagüey) (Fernández Soneira 1997, 242-250; Testé 1973, 651-657).

${ }^{16}$ See Chapter II.

${ }^{17}$ This is a formal weekday instruction for children sponsored by the parish in which it is located. Parochial schools are supported by the deeply held belief of parents and clergy that religious training should be a key element in the daily education of children.

Education at those schools was directed by lay and clergy personnel, and in many cases the schools were under the direction of laypeople members of third orders (A confraternity of laypersons associated with a religious order). The Cuban constitution of 1901, following the United States model, forbade the teaching of religious subjects in public schools. The major efforts to establish parochial schools began in the first decades of the twentieth century as a response to the need to educate the poor children, but also to the increase of the establishment of Protestant schools.

${ }^{18}$ There were numerous lay organizations in Cuba dedicated to the promotion of Catholicism, its values, and doctrine. The ones chosen are representative of their action. They were also selected as they would be congregated later into Catholic Action and its four branches.

${ }^{19}$ This is the Cuban branch of the Catholic Daughters of America (US), as well as the female counterpart to the Knights of Columbus (Fernández Santalices 1998, 22, 23, 27).

${ }^{20}$ Conferencia de Obispos Católicos Cubanos.

${ }^{21}$ Later in 1940 archbishop of San Cristóbal de La Habana, and in 1946 Cardinal of the same diocese. The first Cardinal of Cuba, the Caribbean, and Central America.

${ }^{22}$ The amendment to Article 35, introduced by the members of the Communist Party, eliminated "Christian moral" from the Article on the basis that it could cause the religious persecution of non-Christians. Nuñez had mentioned that introducing that amendment could cause a religious war. Later he added to a rhetorical question from Agüero: "Se ha hecho una exposición que firman más de cincuenta mil cubanos manteniendo ese mismo criterio" (Carbonell Cortina 2001, 202). 
${ }^{23}$ In the literature consulted, the influence that the Academy's projects might have had in the Constitution of 1940 have not been found. Although it is important for this work, a study of such an issue would result on a separate thesis.

${ }^{24}$ As per an interviewee, it was customary for the school staff to ask the parents how much they could contribute for their children's education, and agree to that amount as a symbolic contribution (Eguino 2000).

${ }^{25}$ Same interviewee mentioned that full tuition was usually paid at institutions of higher education, although they also had a similar distribution of scholarships (Eguino 2000)

${ }^{26}$ This is the nobility title for Cardinals.

${ }^{27}$ At the time of his appointment Arteaga was 66 years old.

${ }^{28}$ His mother, urged by Arteaga's uncle, sent him to Venezuela in 1892 to protect him from the harassment the family suffered for political reasons (Céspedes García-Menocal $1996,7)$.

${ }^{29}$ In 1915 over 2000 veterans of the independence war wrote a letter to the Pope requesting to name the Virgen de La Caridad del Cobre patroness of Cuba. Pope Benedict XV, acceded to the petition and on May 10,1916, issued the decree (Portuondo Zuñiga 2001,245) declaring, as requested by the veterans, that May 20 was the feast of the Virgin of Charity Patroness of Cuba (Arteaga y Betancourt 1952, 240). The author of this work has not found the reasons why or when the feast was moved to September 8, but it could have been for political reasons after 1959 .

${ }^{30}$ See appendix 2.

${ }^{31}$ As this political period of Cuba has been so extensively studied, only a brief description is offered with an emphasis on the role and history of Church.

${ }^{32}$ Appendix 3 shows the state of the Church in Cuba in 1959.

${ }^{33}$ See appendix 2 for the growth and decline of clergy in Cuba. Prior to 1937 no statistics were found. 


\section{CHAPTER 5}

\section{Conclusion}

Throughout the colonial years of Cuba many members of the Catholic Church followed their Christian commitment and raised their voices in defense of the socially marginalized, many times against governmental and Church authorities alike. While it is true that many bishops and religious personnel were blindly obedient to the government, and others were inconsistent with their religious vocation, there were others that acted differently. Submission to the crown, and faithfulness to the Catholic doctrine proved to be not always compatible in colonial Cuba.

Fr. Bartolomé de Las Casas, bishop Espada, and Fr. Felix Varela were some of those men who did not remain silent about the authority's injustices nor indifferent towards social needs. Many others, such as Carlos Manuel de Céspedes and Tomás Romay, also educated by the Church, put their ideals and skills to the service and betterment of their fellowmen and eventually of their nation.

Through their voices and actions, the Catholic Church during the colony, established a trend of intellectual development and sociopolitical activism that not only influenced the Cuban socioeconomic growth but also led to the eventual independence of the country from Spain. That independence, which put an end to three decades of death and sorrow, was finally celebrated by over two thousand men and women with a solemn Catholic mass presided over by a Cuban priest, at the sanctuary of Our Lady of Charity. In 1915 , through a petition from over 2000 veterans of the war of independence the Virgen de la Caridad became the Patroness of Cuba. In order to bring together religious 
and national important dates, the feast of the Patroness of Cuba, as also requested by the veterans, was to be celebrated each May $20^{\text {th }}$.

The positive role and influence the Church had on Cuba, however, was still tarnished by the attitudes and actions of those who sided with Spain during the independence wars. The reputation of being a pro-colonialist institution preceded the Church into the next period of Cuban history, in which a provisional military government from the United States occupied the island from 1898 to 1902.

During those years, the Church remained in a sociopolitical limbo, not knowing in which direction the country was going, or even its own role within the newly emerging society. The Church was literally "in between", as it was no longer Spanish, not yet Cuban, and certainly not Anglo-American. Being in between gave the Catholic Church in Cuba sufficient time to rethink its history, to ascertain, to recognize, and to voice its institutional needs, and to begin formulating its plan for "becoming Cuban". No other path other than Cubanizing itself would rid the Church of its anti-Cuban reputation and would gain it the trust and respect of all sectors of the Cuban population. The Cubanization efforts of the Catholic Church in Cuba were a systematically growing campaign throughout the Republic, halted towards the end by the events of 1959-1962.

The advent of the Republic marked the establishment of a Cuban government for the Cuban nation and the appointment of a majoritarian Cuban hierarchy for the Church in Cuba. Once Cuban bishops headed most dioceses, the Cubanization of the Catholic Church serving Cuba achieved a clear and definitive significance. The Church was to become Cuban inasmuch as it strove, within its possibilities and limitations, for the fulfillment of its constituency's needs by providing social services and promoting 
sociopolitical changes. Its missionary work and educational activities were the main tools that allowed the Church to reach its purpose.

For the hierarchy the first step was to launch a serious campaign for the evangelization of the island which began early in the Republic but was never completely achieved due to the changes post-1959. The Misiones Parroquiales became the events through which the bishops entered into close contact with the laity's reality, acquiring, through firsthand observation, a better understanding of the living conditions of the population. That knowledge contributed towards the success of the bishops' pastoral strategies. It also provided crucial information in order to place social services where they were needed the most. Thus the majority of the religious orders and congregations, cooperating with the bishops, were urged and able to establish at least part of their services in the poor and rural areas of the dioceses.

While the Church's ultimate objective was the salvation of souls, the social services it offered, i.e. education and healthcare, were the tangible evidence of its preoccupation for and closeness to the community. They were an effective method employed by the Church in Cuba to diffuse its presence among all sectors of society in order to reach the maximum number of people. Offering social services was a determining factor for the successful Cubanization of the Church. That explains the noticeable impetus of the Church in the foundation of so many schools and health related institutions.

Another factor that determined the Cubanization of the Church was its capability to influence and eventually contribute to the transformation of Cuban society through legislation. Affecting legislation was a direct result of the increase in the interaction 
between the Church and the marginalized sectors of society, specifically the working class. In particular, this was manifested in the conspicuous influence of the works of the Catholic Academy for Social Sciences in the Constitution of 1940.

The increase in the political activities of the Church was also gradual. That increase is clearly seen when the Church's reactions around the constitutional assemblies of 1901 and 1940 are compared. While the actions of the Church were minimal in 1901, they were very noticeable in the Constitution of 1940 . The political interventions of the Church during the Republic were also visible during the events immediately before and after the arrival to power of Fidel Castro, and the intensity of the interaction between Church and government authorities.

The effectiveness of the Church's strategies, and consequently the accomplishment of its Cubanization, is also evident through quantitative factors. One example is the increase in the number of Catholics participating in rituals and ceremonies of the Church and the consequent augment of a committed laity congregated into structured organizations, i.e. Catholic Action. These successes relate to the capability of the Church to mobilize the masses, demonstrated by the lay participation in the different congresses that took place in Cuba, specifically the Catholic National Congress of 1959.

The national and international recognition received by the Catholic Church also shows its institutional prominence. The recognition was epitomized on the persona of the Cuban priest Manuel Arteaga y Betancourt, who was elevated to the Cardinalate by Rome, and who received the Order of Carlos Manuel de Céspedes from his country, among other honors. 
As mentioned in the introduction, there were three interrelated structural factors in part responsible for the enhancement of the functions of the Church in Cuban society. Those factors greatly contributed to the Church's institutional success, and the eventual accomplishment of its goals. In addition, those three factors demonstrate the individual maturity of the Cuban clergy and hierarchy during the Republic ${ }^{1}$.

First, the role of religious personnel was clarified, and that led individuals to a better understanding of their purpose and function within the current structure of the Church. The religious personnel serving in Cuba became increasingly aware of their responsibilities within society and assumed those responsibilities, resulting in a greater involvement in social matters.

The second factor was the level of credibility that the religious personnel acquired within the population. That credibility was achieved as the religious personnel showed evidences of being faithful to their purpose by being responsive to the real needs of the nation. Credibility was reciprocated by the people through the increase in the number of parents wanting to register their children in Catholic schools, and the number of people preferring to use the Church health institutions over those provided by the State. That in turn, resulted in an "explosion" of parochial schools and healthcare institutions being founded throughout the island during the Republic.

Third and final, is the degree of the hierarchical alliance. This is measured by the kind of relationship established among the Church's authority, the religious personnel, and the laity. It is also measured by the influence and popularity the religious leaders had among the constituency. This translates into the leadership capabilities to mobilize the 
masses, which was a very important aspect in the growth and efficacy of the Church's functions within Cuban society.

As Rome reorganized the Church in Cuba and replaced foreigners with native leaders, the degree of identification between the clergy and the hierarchy intensified. As the religious personnel grew to be Cuban, the affinity and sympathy of the laity towards them also increased. Furthermore, the proactive role of the Catholic Church in dealing with social issues had positive, tangible results for the Church and consequently for society.

These three aspects measure not only the level of identification of the religious personnel with its constituency but also the level of identification of the constituency with the religious personnel. These aspects allow the Catholic Church serving Cuba to be defined as a gradually increasing influential and proactive institution during the Republic. In approximately sixty years, it evolved from being perceived as a pro status quo organization at the end of the colony, through being in a sociopolitical limbo during the United States occupation, to becoming a Church whose services were highly in demand, and that promoted sociopolitical positive changes, targeting the well being of the population

As we have seen, several factors that intervened in the success of the Church in becoming Cuban. Taking the steps that moved the Church from being the Church in Cuba to being the Church of Cuba was not achieved through a separation from Rome and the establishment of a national Church. The Cuban Catholic hierarchy, the clergy, and the laity during the Republic were able to demonstrate that the catholicity and Cubanness of the Church were not in contradiction. The Catholic Church of Cuba was capable of 
successfully combining its faithfulness to Rome with its adherence to the Cuban nation and its needs, by reconciling missionary work, human services, and the promotion of sociopolitical reforms.

At the end of the Republic, the Church had obviously overcome its anti-Cuban stigma. Other serious problem areas, however, still remained. The reduced religious presence in the countryside, demonstrated in a survey undertaken by ACU, was the next problem the Catholic Church of Cuba was to overcome. The survey, and the intense reorganization undertaken by the Church were the precursors of the massive evangelization of the island the Church was preparing when the political turmoil of the late 1950s unfolded. The torch march that preceded the Catholic National Congress mass at the Civic Plaza in 1959, which was coming from the four cardinal points of the island, symbolically represented that massive evangelization of Cuba which was to be concentrated in the countryside. That enormous concentration of Cuban Catholics of 1959 , that was to mark the beginning of the new evangelization of the island, instead, marked its end.

As it had happened at the end of the colonial period, the positive role that the Church had in Cuban society, and the efforts of the Catholic Church in Cuba during the Republic, went unrecognized, and even to date lack recognition. The literature that emerged post 1959, inland and abroad, focused mostly on the events that led to and followed the Revolution. The role of the Church was criticized by some and overlooked by others. Fortunately, there is always time to rethink historical events, and rewrite history from a different perspective. 
Such is the case of some intellectuals such as the historian of La Habana, Eusebio Leal, who, besides being responsible for the reconstruction of the old section of the city, is contributing to the reconstruction of the history of the island. During a conference offered at the Aula Fray Bartolomé de Las Casas, at the Dominican Priory of San Juan de Letrán in La Habana, Leal, who studied for some years at the Seminario San Carlos and San Ambrosio pronounced the following words that have been chosen to conclude this study:

"Seria mezquino, seria injusto y seria por sobre todo inculto que no se analizaran y se pusiesen en su lugar el valor grande que tuvieron en la formación de la nación cubana instituciones como el Seminario y como la Iglesia misma, que tuvo hombres tan prominentes ... hombres tan constructores, tan trabajadores, tan luchadores como aquellos que rodeando a este clero trataron de conciliar fe $y$ religión; religión y sociedad; monarquía y patria"

(Eusebio Leal, conference offered at the Aula Fray Bartolomé de Las Casas, in the Dominican Priory of San Juan de Letrán, on November 23, 1995).

\section{Notes}

${ }^{1}$ For a complete description, see Nygren and Ukeritis 1993, 143, 149, 159. 


\section{LIST OF REFERENCES}

Acción Católica. 1946. Organización de la Acción Católica Cubana. Boletin Oficial de la Provincia Eclesiástica de la República de Cuba. La Habana, Cuba: January 30.

Ambrosio, Arzobispo Félix. 1917. Mandato del 20 de Octubre de 1917. Boletin Oficial de la Provincia Eclesiástica de la República de Cuba. La Habana, Cuba: November 30.

Antoine. 1909. Visita Pastoral de Mons. González Estrada a Guanabacoa. Boletín Oficial de la Provincia Eclesiástica de la República de Cuba. La Habana, Cuba: April 30.

Aragón, Uva De. 2002. La República: La Constitución de 1901. Diario Las Américas, Miami, FL: January 24.

Aramburo y Machado, Mariano. 1920. Discurso de presentación ante el Senado de la República de Cuba, 20 de julio de 1920. Photocopied from a copy located at the Dominican Convent of San Juan de Letrán, in La Habana, in December 2001. Copy in the possession of the author.

Arteaga y Betancourt, Manuel. 1940. Circular del 20 de Junio de 1940. Boletin Oficial de la Provincia Eclesiástica de la República de Cuba. La Habana, Cuba: June/July.

1945. Carta Pastoral de Enero de 1945. Boletín Oficial de la Provincia Eclesiástica de la República de Cuba. La Habana, Cuba: January 30.

1950. Discurso Pronunciado por el Emmo. y Rvdmo. Sr. Manuel, Cardenal Arteaga y Betancourt, Arzobispo de La Habana, en la Universidad de Tampa con ocación de la Clausura del Curso 1949-1950 y de su investidura como Doctor en Leyes "Honoris causa" en la misma Universidad, 28 de Mayo de 1950. Boletín Oficial de la Provincia Eclesiástica de la República de Cuba. La Habana, Cuba: July 30 .

- 1951. Los aciagos problemas de la era actual. Boletín Oficial de la Provincia Eclesiástica de la República de Cuba. La Habana, Cuba: July 30.

1951. Peregrinacion por el 20 de Mayo. Boletín Oficial de la Provincia Eclesiástica de la República de Cuba. La Habana, Cuba: July 30.

Baez, Vicente ed. 1973. III. La Enciclopedia de Cuba, Novela. Costumbrismo. Madrid, España: Playor, S.A.

1974. La Enciclopedia de Cuba, Historia. IV. Madrid, España: Playor, S.A. 
. 1975. La Enciclopedia de Cuba, Gobiernos Republicanos. IX. Madrid, España: Playor, S.A.

Belda Mas, Jesús. 1999. Cuba, ¿a dónde vas? Valencia, España: GUADA Litografía.

Buch Sánchez, Rita. 1999. "El Seminario San Carlos y San Ambrosio como taller de la nación cubana". In Pensar en Cuba, Debates historiográficos. Rafael Acosta et al. La Habana, Cuba: Editorial de Ciencias Sociales. 71-108.

Carbonell Cortina, Néstor. 2001. Grandes debates de la constituyente cubana de 1940. Miami, FL: Ediciones Universal.

Cartaya Cotta, Perla. 2000. Como un Grano de Mostaza, acercamiento a la vida y obra del Padre Jerónimo Usera a 110 años de su muerte. Palabra Nueva, Revista de la Arquidiócesis de La Habana. La Habana, Cuba: May. 84.

Céspedes García-Menocal, Carlos Manuel de. 1998. Pasión por Cuba y por la Iglesia. Aproximación biográfica al Padre Varela. Madrid, España: Biblioteca de Autores Cristianos.

. 1996. Imagen Luminosa de un hombre cuestionado. Intento de aproximación a la persona del Eminentísimo Señor Cardenal Manuel Arteaga y Betancourt, Arzobispo de La Habana. La Habana, Cuba: August 20. Photocopy of a manuscript given by Msgr. Carlos Manuel in December 2001 is held by the author of this thesis.

. 2001. Interview with Leonardo Falcón, La Habana, Cuba: December. Recording in possession of author.

Chaurrondo, Hilario. 1951. La Obra de las Misiones Parroquiales cumple sus Bodas de Plata. Boletín Oficial de la Provincia Eclesiástica de la República de Cuba. La Habana, Cuba: May 30.

Clark, Juan. 1986. Religious Repression in Cuba. Miami, FL: North-South Center for The Cuban Studies Project of the Institute of Interamerican Studies, University of Miami.

COCC . 1995. (Conferencia de Obispos Católicos Cubanos). La Voz de la Iglesia, 100 documentos episcopales. Mexico: Obra Nacional de la Buena Prensa, A.C.

Comité. 1914. Carta del Comité Central de los Obreros Católicos: El clero acude en ayuda de los obreros. Boletín Oficial de la Provincia Eclesiástica de la República de Cuba. La Habana, Cuba. September 30. 
Constitution 1940. In Baez, Vicente ed. 1975. IX. La Enciclopedia de Cuba, Gobiernos Republicanos. Madrid, España: Playor, S.A. 594-635.

Costa, Octavio R. 1998. Imágen y Trajectoria del Cubano en la Historia, La República (1902-1959). Miami, FL: Ediciones Universal.

Crahan, Margaret. 1989. "Catholicism in Cuba". In Cuban Studies 19. Edited by Carmelo Mesa-Lago. Pittsburgh, PA: Pittsburgh University Press. 3-24.

De Casa. 1915. Visita Pastoral y Confirmación en la Iglesia y Parroquia del Pilar. Boletín Oficial de la Provincia Eclesiástica de la República de Cuba. La Habana, Cuba: April 30.

Díaz, Maria Elena. 2000. "Rethinking Tradition and Identity. The Virgin of Charity of El Cobre". In Cuba, the Elusive Nation. Edited by Damián J. Fernández and Madeline Cámara Betancourt. Gainesville, FL: University Press of Florida. 43-59.

Dominguez, Jorge I. 1989. "International and National Aspects of the Catholic Church in Cuba". In Cuban Studies 19. Edited by Carmelo Mesa-Lago. Pittsburgh, PA: Pittsburgh University Press. 43-60.

DREC . 1962. (Directorio Revolutionario Estudiantil Cubano). La Persecución de la Iglesia Católica en Cuba. Quito, Ecuador.

Editorial. 1942. Habemus Pontificem. Boletín Oficial de la Provincia Eclesiástica de la República de Cuba. La Habana, Cuba: January 30.

. 1946. ¡Un Cardenal Cubano! Boletín Oficial de la Provincia Eclesiástica de la República de Cuba. La Habana, Cuba: January 30.

Eguino 2000. Interviews with Leonardo Falcón, November 12 and 19. Miami, FL. Recording in possession of author.

El Corresponsal. 1910. La Visita del Señor Obispo el 3 de Febrero de 1910. Boletín Oficial de la Provincia Eclesiástica de la República de Cuba. La Habana, Cuba: March 30.

ENEC. 1987. (Encuentro Nacional Eclesial Cubano). Documento Final e Instrucción Pastoral de los Obispos de Cuba. Roma, Italia: Tipografia Don Bosco.

Fernández, Damián. 2000. Cuba and the Politics of Passion. Austin, TX: University of Texas Press.

Fernández Santalices, Manuel. 1998. Presencia en Cuba del Catolicismo, apuntes históricos del siglo veinte. Caracas, Venezuela: Laser Gráfica. 
. 2001. Cronología Histórica de Cuba, 1492-2000. Miami, FL: Ediciones Universal.

Fernández Soneira, Teresa. 1997. Cuba, Historia de la Educacion Católica 1582-1961. I, II. Miami, FL: Ediciones Universal.

Fernández 2002. Interview with Leonardo Falcón, January 7. La Habana, Cuba. Recording in possession of author.

Fr. 2001. Personal interviews with a priest by Leonardo Falcón. He still lives in Cuba and preferred his name not to be mentioned. December 19 and 22. La Habana, Cuba.

Fraga, Rafael. 1914. La Iglesia Católica en favor de la clase obrera. La Lucha, Septiembre 1 de 1914. Reprinted in Boletín Oficial de la Provincia Eclesiástica de la República de Cuba. La Habana, Cuba: September 30.

Gacetilla. 1921. News appendix to Revista Antillana. Edited by Aramburo y Machado et al. La Habana, Cuba: Maza, Arroyo y Caso, S, en C. 51-52.

García Pons, Cesar. 1951. El Obispo Espada y su influencia en la cultura cubana. La Habana, Cuba: Editorial Librería Selecta.

García Rodriguez, Mercedes. 2000. Misticismo y Capitales. La Compañia de Jesús en la economia habanera del siglo XVIII. La Habana, Cuba: Editorial Ciencias Sociales.

Garrote Amigo, Santiago. 1919. Fundación de la Academia Católica de Ciencias Sociales. Boletín Oficial de la Provincia Eclesiástica de la República de Cuba. $\mathrm{La}$ Habana, Cuba: November 30.

González Bacallao, Obispo José Siro. 2000. "Octogésimo aniversario de la fundación de la Academia Católica de Ciencias Sociales". In Cuadernos del Aula Fray Bartolomé de Las Casas 4. Edited by Carmen Cañizares. Frailes Dominicos, Convento de San Juan de Letrán, La Habana, Cuba. 15-24.

González Estrada, Obispo Pedro Ladislao. 1904. Reaparición del Boletín. Boletín Oficial de la Provincia Eclesiástica de la República de Cuba. La Habana, Cuba: January 30 .

1904. Sección Official, Circulares. Circular Num. 2. Boletín Oficial de la Provincia Eclesiástica de la República de Cuba. La Habana, Cuba: February 29.

1905. Edicto, Sección Oficial. Boletín Oficial de la Provincia Eclesiástica de la República de Cuba. La Habana, Cuba: May 30. 
Grandiosa Misión. 1951. Misión Parroquial en San Antonio de los Baños. Boletín Oficial de la Provincia Eclesiástica de la República de Cuba. La Habana, Cuba: May 30.

Guerra y Sánchez, Ramiro et al. 1958. A History of the Cuban Nation, Vol. 3, Illustration freedom of Commerce. La Habana, Cuba: Editorial Historia de la Nación Cubana, S.A.

Ibarra, Jorge. 1981. Nación y Cultura Nacional. La Habana, Cuba: Editorial Letras Cubanas.

Isern, Juan. 1921. "Viviendas para Obreros". In Revista Antillana. Edited by Aramburo y Machado et al. La Habana, Cuba: Maza, Arroyo y Caso, S, en C. 276-289.

Kirk, John M. 1989a. Between God and The Party. Religion and Politics in Revolutionary Cuba. Tampa, FL: University of South Florida Press.

.1989b. Toward and Understanding of the Church-State Rapprochement in Revolutionary Cuba. In Cuban Studies 19. Edited by Carmelo Mesa-Lago. Pittsburgh, PA: Pittsburgh University Press. 25-42.

Larrúa Guedes, Salvador. 1996. Principales Figuras y Sucesos de la Iglesia Cubana. Santo Domingo, Republica Dominicana: Publicaciones del Centro de Estudios Sociales P. Juan Montalvo, S.J.

1997. Presencia de los Dominicos en Cuba, desde fray Bartolomé de Las Casas hasta el momento actual. Santa Fé de Bogotá, Colombia: Universidad Santo Tomás.

. 1998. Historia de la Orden de Predicadores en la Isla de Cuba. Santa Fé de Bogotá, Colombia: Siglo XXI Impresores Ltda.

Leal, Eusebio. 1997. "Seminario y Nación. El Siglo de Oro de la Cultura Cubana". In Cuadernos del Aula Fray Bartolomé de Las Casas 1. Edited by Carmen Cañizares. Frailes Dominicos, Convento de San Juan de Letrán, La Habana, Cuba. 87-104.

Lebroc Martinez, Reinerio. 1985. Episcopologio. Miami, FL: Ediciones Hispamerican Books.

Leiseca, Juan Martín. 1938. Apuntes para la Historia Eclesiástica de Cuba. La Habana, Cuba: Talleres Tipográficos de Carasa y Cia.

L'Obsservatore Romano. 1944. La Acción Católica Cubana, 20 de Febrero de 1944. Reprinted in Boletín Oficial de la Provincia Eclesiástica de la República de Cuba. La Habana, Cuba: September 30. 
Lockmiller, David A. 1938. Magoon in Cuba: A History of the Second Intervention, 1906-1909. New York, NY: Greenwood Press Publishers.

Marrero, Leví. 1972. Cuba Economía y Sociedad. II. Madrid, España: Editorial Playor S.A., 14 Vols. In Segreo, Rigoberto R. De Compostela a Espada, Vicisitudes de la Iglesia Católica en Cuba. La Habana, Cuba: Editorial Ciencias Sociales, 2000.

Martinez Sánchez, Carlos. 1975. "Génesis y significación de la Constitución del 1940". In Baez, Vicente ed. La Enciclopedia de Cuba, Gobiernos Republicanos. IX. Madrid, España: Playor, S.A. 581-593.

Maza Miquel, Manuel. 1999. Esclavos Patriotas y Poetas a la sombra de la cruz. Cinco ensayos sobre catolicismo e historia cubana. Santo Domingo, Republica Dominicana: Publicaciones del Centro de Estudios Sociales P. Juan Montalvo, S.J.

McCarthy, Timothy G. 1994. The Catholic Tradition. Before and after Vatican II 18781993. Chicago, IL: Loyola University Press.

McGee, Jon R. and Warms, Richard L. eds. 2000. Anthropological Theory, an Introductory History. Mountain View, CA: Mayfield Publishing Company.

Meier, Johannes et al. 1995. Historia General de la Iglesia en América Latina Vol. IV Caribe. Chetumal, Mexico: Ediciones Sígueme, Universidad de Quintana Roo.

Memorias . 1921. Las Memorias que los P.P. Dominicos de La Habana dedican a su excelso fundador Santo Domingo de Guzmán, en el VII Centenario de su preciosa muerte (1221-1921). La Habana, Cuba: Talleres Tipográficos Religiosos de Seoane y Fernández. Photocopy of the original kept at the Dominican Priory of San Juan de Letrán in Havana, Cuba.

Movimiento Catequístico en la Arquidiócesis. 1946. Censo. Boletín Oficial de la Provincia Eclesiástica de la República de Cuba. La Habana, Cuba: April 30.

Nygren, David J., and Ukeritis, Miriam D. 1993. The Future of Religious Orders in the United States. Transformation and Commitment. Westport, CT: Praeger Publishers.

Pérez, Lisandro. 1994. "Cuban Catholics in the United States". In Puerto Rican and Cuban Catholics in the United States, 1900-1965. Edited by Jay P. Dolan and Jaime R. Vidal. Notre Dame, IN: University of Notre Dame Press. 147-247.

Pérez Jr., Louis A. 1999. On Becoming Cuban. Identity, Nationality, and Culture. Chapel Hill, NC: University of North Carolina Press. 
Pérez Serantes, Obispo Enrique. 1942. A la federación de la Juventud Católica Cubana, con motivo de la II Concentración Nacional, por el Excmo. y Rvdmo. Sr. Dr. Enrique Pérez Serantes Obispo de Camagüey. Boletín Oficial de la Provincia Eclesiástica de la República de Cuba. La Habana, Cuba: December 30.

Pérez-Stable, Marifeli. 1999. The Cuban Revolution. Origins, Course, and Legacy. New York, NY: Oxford University Press, $2^{\text {nd }}$ edition.

Portuondo Zuñiga, Olga. 2001. La Virgen de la Caridad del Cobre: Símbolo de Cubanía. Santiago de Cuba, Cuba: Editorial Oriente.

R.D. 1911. Misión Parroquial in San Antonio de los Baños. Boletín Oficial de la Provincia Eclesiástica de la República de Cuba. La Habana, Cuba: January 31.

Rerum Novarum. Accessed on 04/15/2001. Available at:

http://www.vatican.va/holy_father/leo_xiii/encyclicals/documents/hf_1xiii_enc_15051891_rerum-novarum_en.html

Rodriguez, Manuel. 1914. Relación de las cantidades recibidas por subscripción voluntaria abierta por el Clero de esta Diócesis de La Habana, para socorrer a los obreros sin trabajo. Boletín Oficial de la Provincia Eclesiástica de la República de Cuba. La Habana, Cuba: September 30.

Sainz, Severino. 1914. Circular del 29 de Agosto de 1914. Boletín Oficial de la Provincia Eclesiástica de la República de Cuba. La Habana, Cuba: September 30.

Segreo Ricardo, Rigoberto. 2000. De Compostela a Espada, Vicisitudes de la Iglesia Católica en Cuba. La Habana, Cuba: Editorial de Ciencias Sociales.

Soneira, Abelardo Jorge. 1989. Las estrategias de la Iglesia Católica en la Argentina (1880-1976). Buenos Aires, Argentina: Centro Editor de America Latina S.A.

Testé, Ismael. 1969. Historia Eclesiástica de Cuba. I. Burgos, España: Tipografía de la Editorial "Monte Carmelo".

. 1970. Historia Eclesiástica de Cuba. II. Burgos, España: Tipografia de la Editorial "Monte Carmelo".

. 1973. Historia Eclesiástica de Cuba. III. Burgos, España: Tipografia de la Editorial "Monte Carmelo".

.1974. Historia Eclesiástica de Cuba. IV. Barcelona, España: Complejo de Artes Gráficas MEDINACELI, S.A. 
. 1975. Historia Eclesiástica de Cuba. V. Barcelona, España: Complejo de Artes Gráficas MEDINACELI, S.A.

Thomas, Hugh. 1998. Cuba or The Pursuit of Freedom. New York, NY: Da Capo Press, Second Updated Edition.

Turner, Frederic. 1971. Catholicism and Political Development in Latin America. Chapel Hill, NC: The University of North Carolina Press.

Ubi Arcano Dei Consilioi. Accessed on April 2002. Available at:

www.vatican.va/holy_father/pius_xi/encyclicals/documents/hf_p-

xi_enc_23121922_ubi-arcano-dei-consilio_en.html

Un Católico. 1903. Desde Jaruco. Boletín Oficial de la Provincia Eclesiástica de la República de Cuba. La Habana, Cuba: February 28.

Variedades. 1905. Apertura del Seminario Conciliar de San Carlos y San Ambrosio. Boletín Oficial de la Provincia Eclesiástica de la República de Cuba. La Habana, Cuba: October 31.

- 1914. La Iglesia en favor de los obreros. Boletín Oficial de la Provincia Eclesiástica de la República de Cuba. La Habana, Cuba: December 30.

1915. De Casa. Boletín Oficial de la Provincia Eclesiástica de la República de Cuba. La Habana, Cuba: January 30.

Varela, Félix. 1992. Miscelánea Filosófica. Edited by M. B. González Barranco. La Habana, Cuba: Editorial Pueblo y Educación.

Zubizarreta, Valentin et al. 1939. Carta Pastoral que los Excmos. y Rms. Sres. Arzobispos y Obispos de Cuba dirigen a sus fieles sobre la Acción Católica, Diciembre 17 de 1938. Boletín Oficial de la Provincia Eclesiástica de la República de Cuba. La Habana, Cuba: January 30. 


\section{APPENDIX 1}

Educational institutions founded by the Catholic Church in Cuba in the $20^{\text {th }}$ century Padres Dominicos:

1. Colegio Parroquial del Vedado (1920)

2. Escuela Parroquial de Santa Rosa (1920s*)

3. Escuela Parroquial de Santa Catalina (1920s*)

4. Escuela Parroquial de Santo Domingo (1920s*)

5. Escuela Parroquial de Jesús Obrero (1930s*)

6. Academia Católica de Ciencias Sociales (1919)

7. Escuela Bartolomé de las Casas (Cienfuegos)

8. Escuela Parroquial de niñas Santa Cruz en Prado (1910)

9. Escuela Parroquial de los niños de Santa Elena y Prado (1910s*)

10. Escuela de Comercio (Cienfuegos) (1907)

11. Escuela Azucarera (Cienfuegos) (1909)

12. Escuela de Agrimensura (Cienfuegos) (1909)

13. Escuela Parroquial de Trinidad (1920s*)

Compañía de Jesús - Jesuitas:

14. Colegio de Belén de Marianao (1925)

15. Colegio del Sagrado Corazón (Sagua) (1907)

16. Colegio de Dolores (Santiago de Cuba) (1911)

17. Escuela Electromecánica (1941)

Padres Capuchinos:

18. Colegio de Bayamo (1913)

19. Colegio de San Antonio de Padua (Cruces) (1924)

20. Colegio de Colegio de Santa Clara (1949)

21. Colegio-Academia Cristo de Limpias (1958)

Hijas de la Caridad de S. Vicente de Paúl:

22. Colegio Jésus María (Habana) (1901)

23. Colegio La Milagrosa (Matanzas) (1902) 
24. Colegio Nuestra Señora de la Caridad (Güines) (1903)

25. Colegio Sagrado Corazón de Jesús (Güira de Melena) (1915)

26. Colegio la Santa Infancia (S. Antonio de los Baños) (1916)

27. Colegio-Asilo Hijas de María (Santiago de Cuba) (1900)

28. Asilo Menocal (Cerro) (1940)

29. Asilo y Creche del Vedado (1919)

30. Asilo Creche Mina Truffin (Habana) (1918)

31. Academia San José (Nueva Gerona, Isla de Pinos) (1926)

32. Colegio Nuestra Señora de la Caridad (El Cristo, Oriente) (1954)

33. Colegio Cervantes (Baracoa) (1958)

\section{Instituto de María Inmaculada - Claretianas:}

34. Colegio de Palma Soriano (1922)

35. Colegio de la Habana (1947)

36. Colegio de San Luis (Oriente) (1950)

\section{Religiosas del Sagrado Corazón de Jesús:}

37. Colegio de Santiago de Cuba (1911)

\section{Padres Escolapios:}

38. Escuelas Pías de San José de Calasanz (San Rafael, Habana) (1904)

39. Colegio del Pilar (Cerro) (1910s*)

40. Colegio de Cárdenas (1910)

41. Colegio Virgen de La Merced (Pinar del Rio) (1910)

42. Colegio del Vedado (1930)

43. Colegio Nuestra Señora de Fátima (Víbora) (1930)

\section{Hermanas del Amor de Dios:}

44. Colegio de Remedios (1909)

45. Colegio Nuestra Señora de la Caridad (Palatino) (1925)

46. Colegio Nuestra Señora del Pilar (Habana) (1928)

47. Asilo de Niños Pobres Colón (Matanzas) (1935)

48. Colegio de San José de las Lajas (1925)

49. Colegio del Central Francisco (Camagüuey) (1953) 
50. Colegio de Fomento (Santa Clara) (1953)

51. Colegio de Santa Cruz del Sur (Camagüey) (1954)

52. Colegio Usera (Santa Clara) (1954)

53. Colegio de Ranchuelo (Santa Clara) (1955)

54. Colegio de Campo Florido (Habana) (1955)

55. Colegio Lugareño (Camagüey) (1955)

56. Colegio de Cumanayagua (Las Villas) (1957)

57. Colegio de El Cotorro (Habana) (1957)

Misioneros del Inmaculado Corazón de María (Claretianos):

58. Colegio de Palma Soriano (Oriente) (1919)

59. Colegio de Varadero (Matanzas) (1940)

60. Colegio de Cárdenas (Matanzas) (1952)

61. Colegio de la Habana (1949)

62. Colegio de Santiago de Cuba (1957)

Hermanas de la Caridad del Sagrado Corazón de Jesús :

63. Colegio-Asilo San José (Mijala,Cárdenas) (1917)

64. Colegio Santa Rosalia (Palatino, Habana) (1932)

Religiosas del Apotolado del Sagrado Corazón de Jesús :

65. Colegio de Cienfuegos (1903)

66. Colegio de Sagua la Grande (1910)

67. Colegio de Caibarién (1914)

68. Colegio de Sancti Spíritus (1915)

Congregación de Nuestra Señora Del Stmo. Rosario

Dominicas Francesas:

69. Colegio de la Habana (1903)

70. Escuela Gratuita de Santa Catalina de Siena (Habana) (1920s*)

71. Colegio de San Miguel de los Baños (1920s*)

72. Colegio de Fomento (Las Villas) (1932)

73. Colegio de la Esperanza (Las Villas) (1936) 


\section{Padres Pasionistas:}

74. Colegio San Pablo de la Cruz (1900)

75. Colegio de Holguín (1936)

\section{Padres Trinitarios:}

76. Colegio de la Santísima Trinidad (Lawton) (1952)

\section{Padres Benedictinos:}

77. Colegio St. Joseph's (Nueva Gerona, Isla De Pinos) (1900)

\section{Dominicas Americanas:}

78. American Dominican Academy (Habana) (1900)

79. Colegio Nuestra Sra. Del Rosario (Cienfuegos) (1908)

Hermanas Oblatas de la Divina providencia:

80. Colegio Dulce Nombre de María (Habana) (1900)

81. Colegio San José (Cárdenas) (1908)

82. Colegio Nuestra Señora del Cármen (Santa Clara) (1910)

83. Colegio la Inmaculada (Camagüey) (1924)

84. Mother Consuella Clifford Academy (Marianao) (1934)

85. Mother Mary Lange School (Santiago de Cuba) (1957)

\section{Padres Agustinos:}

86. Colegio San Agustín (1901)

87. Escuela Gratuita de Cristo (1945)

88. Universidad de Santo Tomás de Villanueva (1946)

\section{Hermanos Maristas:}

89. Colegio Francés (Cienfuegos) (1903)

90. Colegio de Remedios (1908)

91. Colegio Sagrado Corazón (Caibarién) (1914)

92. Colegio Francés de Párraga (1915)

93. Colegio Champagnar (Víbora) (1918)

94. Colegio Champagnar (Camagüey) (1936)

95. Colegio de Ciego de Avila (1926)

96. Primaria del Colegio Champagnar (Cienfuegos) (1929) 
97. Academia Champagnar del Cerro (1933)

98. Colegio Champagnar (Santa Clara) (1933)

99. Colegio de Holguín (1954)

Hermanos de la salle:

100. Colegio de idiomas y comercio San

Juan Bautista De La Salle (La Habana) (1905)

101. Colegio de la Salle (Vedado) (1910)

102. Escuela el Niño de Belén (Habana) (1905)

103. Orfelinato-Escuela San Vicente de Paúl (Habana) (1906)

104. Colegio la Natividad (Sancti Spiritus) (1907)

105. Colegio San Julián (Güines) (1907)

106. Colegio Nuestra Señora de la Caridad (Santiago de Cuba) (1908)

107. Escuela Gratuita de San Diego de los Baños (Pinar del Rio) (1914)

108. Colegio Sagrado Corazón (Sagua) (1914)

109. Colegio San Antonio Abad (San Antonio de los Baños) (1914)

110. Colegio Sagrado Corazón (Guantánamo) (1914)

111. Colegio San Cristóbal (Regla) (1915)

112. Academia de La Salle (Habana) (1915)

113. Escuela Gratuita Anexa al Colegio de la Salle (Vedado) (1916)

114. Colegio San José (Marianao) (1918)

115. Colegio de La Salle (Marianao) (1941)

116. Colegio de La Salle (Palatino) (1948)

117. Escuela Gratuita Santa María del Rosario (1945)

118. Universidad Social Católica

San Juan Bautista de La Salle (Habana) (1957)

119. Colegio de La Salle (Manzanillo) (1958)

120. Escuela gratuita de San Vicente (Santiago de Cuba) (1959)

Misioneras Corazón de María:

121. Colegio Inmaculado Corazón de María (Pinar del Rio) (1911)

122. Colegio Corazón De María (La Habana) (1920) 
123. Colegio Hispano Americano (Colon,Matanzas) (1926)

124. Colegio Nuestra Señora de la Caridad del Cobre (Banes) (1947)

125. Colegio Inmaculado Corazón de María (Cabaiguán) (1951)

126. Colegio Inmaculado Corazón de María (Guayos) (1953)

127. Colegio Inmaculado Corazón de María (San Juan y Martinez) (1954)

128. Colegio Inmaculado Corazón de María (Piña-Moron) (1954)

Esclavas del sagrado Corazón de Jesús:

129. Colegio-Talleres ACI, Luyano (Habana) (1921)

130. Colegio de Miramar (1949)

Benedictinas de Pennsylvania:

131. Academia de St. Joséph's (Nueva Gerona, Isla de Pinos) (1912)

Madres escolapias:

132. Colegio Nuestra Señora de los Dolores (Guanajay) (1912)

133. Colegio Nuestra Señora del Sagrado Corazón (Artemisa) (1913)

134. Colegio-Asilo La Milagrosa (Casablanca) (1913)

135. Colegio Nuestra Señora del Buen Consejo (La Habana) (1917)

136. Colegio del Cerro (Habana) (1929)

137. Colegio Nuestra Señora del Buen Pastor (1929)

138. Colegio María Encarnación (Cárdenas) (1920)

139. Colegio Sagrado Corazón de Jesús (Morón) (1921)

Hijas Misioneras del calvario:

140. Colegio la Sagrada Familia (Luyanó) (1916)

141. Colegio El Cotorro (Lawton) (1935)

Hermanas de San Felipe Neri (Filipenses):

142. Colegio Nuestra Señora de Lourdes (1914)

143. Colegio Santa Catalina (1921)

144. Colegio El Apostolado (1925)

145. Colegio Inmaculada Concepcíon (Matanzas) (1955)

146. Colegio el Buen Patstor (Puerto Padre,Oriente) (1955) 


\section{Compañía de Santa Teresa de Jesús:}

147. Colegio Nuestra Señora del Cármen (La Habana) (1915)

148. Colegio Teresiano de Camagüey (1915)

149. Colegio Teresiano de Santa Clara (1915)

150. Colegio Teresiano de Guantánamo (1915)

151. Colegio Teresiano de Ciego de Ávila (1916)

152. Colegio Teresiano de Cienfuegos (1926)

153. Colegio Teresiano Saratoga-Camagüey (1953)

\section{Religiosas del Verbo Encarnado:}

154. Colegio de Camajuaní (1916)

155. Colegio de Trinidad (1916)

156. Colegio de Cruces (1916)

157. Colegio Santa Isabel de las Lajas (1916)

158. Colegio de Cienfuegos (1917)

159. Colegio Nuestra Señora del Rosario (Trinidad) (1920)

160. Colegio de Encrucijada (1937)

161. Colegio Nuestra Señora de la Caridad (Victoria de las Tunas) (1946)

162. Colegio Nuestra Señora de Fatima (Habana) (1947)

163. Colegio de Manatí (Victoria de las Tunas) (1951)

Religiosas de María Inmaculada:

164. Academia de la Habana (1916)

\section{Padres salesianos:}

165. Institución Inclán (Víbora) (1920)

166. Colegio Don Bosco (Santiago de Cuba) (1921)

167. Colegio Dolores Bentancour (Camagüey) (1919)

168. Colegio San Juan Bosco (Guanabacoa) (1926)

169. Noviciado Sto. Domingo Savio (Arroyo Naranjo) (1954)

170. Colegio Salesiano San Julián (Guines) (1936)

171. Colegio San Juan Bosco (Vibora) (1949)

172. Colegio Rosa Pérez Velasco (Santa Clara) (1956) 


\section{Religiosas Pasionistas:}

173. Colegio la Inmaculada (Habana) (1916)

174. Colegio Nuestra Señora de los Remedios (Sabanilla del Encomendador) (1916)

175. Colegio Nuestra Señora de los Ángeles (Unión de Reyes) (1918)

176. Colegio Nuestra Señora de Guadalupe (Santa Fé) (1947)

Hermanas Capuchinas de la Divina Pastora:

177. Colegio Divina Pastora (Bayamo) (1921)

178. Colegio Divina Pastora (Marianao) (1947)

Salesianas (Hijas de María Auxiliadora):

179. Colegio Dolores Betancour (Camagüey) (1922)

180. Colegio de Nuevitas (1926)

181. Colegio Compostela (Habana Vieja) (1930)

182. Colegio La Vigía (Camagüey) (1935)

183. Asilo San Juan Bosco (Sancti Spiritus) (1936)

184. Colegio Santa María Mazzarello (Camagüey) (1936)

185. Colegio de Guaimaro (Camagüey) (1936)

186. Asilo-Granja Nuestra Señora de la Caridad (Lawton) (1936)

187. Colegio de Santiago de Cuba (1936)

188. Colegio María Auxiliadora (Víbora) (1937)

189. Colegio San Juan Bosco (Habana) (1937)

190. Colegio María Auxiliadora y Aspirantado y Postulantado (Santiago de las Vegas) (1937)

191. Colegio Santa Teresita (Sancti Spiritus) (1942)

\section{Mercedarias Eucarísticas:}

192. Colegio Eucarístico (Placetas) (1925)

193. Colegio Eucarístico la Purisima (Habana) (1926)

194. Colegio Eucarístico del Vedado (1926)

195. Colegio Eucarístico de Marianao (1950)

196. Colegio Eucarístico (Camajuani) (1941) 
197. Colegio Eucarístico Santa Teresita (Central Prestón,Oriente) (1958)

Hijas Mínimas de María Inmaculada:

198. Colegio de Cruces (1925)

199. Colegio Santa Isabel de las Lajas (1920s*)

200. Colegio de Aguada de Pasajeros (1930s*)

Siervas de San José:

201. Colegio Nuestra Señora de la Asuncíon (Habana) (1926)

202. Colegio San José (Placetas) (1944)

Compañía de María (Lestonnac):

203. Colegio de Florida (Camagüey) (1926)

204. Colegio de Holguín (1926)

205. Colegio de Puerto Padre (1926)

206. Colegio de Manzanillo (1927)

207. Colegio de la Habana (1927)

Siervas del Sagrado Corazón de Jesús y de los Pobres:

208. Colegio del Sagrado Corazón de Jesús (Nueva Paz, Habana) (1926)

209. Colegio Sagrado Corazón de Jesús (Jaruco) (1927)

210. Colegio Santa María de los Angeles (Víbora) (1927)

211. Colegio de Güira de Melena (Habana) (1927)

Ursulinas Norteamericanas:

212. Merici Academy (Habana) (1941)

Misiones Extranjeras (Padres Canadienses):

213. Escuela Técnica de Matanzas (1942) (1942)

214. Escuela Padre Varela (Colón) (1942)

Misioneras Siervas de la Santísima Trinidad:

215. Colegio y dispensario de San Agustín (Habana) (1948)

Carmelitas Misioneras:

216. Colegio Virgen del Carmen (Habana) (1953)

217. Colegio Virgen del Carmen (Vertientes, Camagüey) (1953)

218. Colegio Santa Teresita (Vertientes, Camagüey) (1959) 
Siervas del Stmo. Corazón de María:

219. Colegio María Auxiliadora (Caraballo) (1950)

220. Colegio María Auxiliadora (San Antonio del Río Blanco) (1952)

221. Colegio María Auxiliadora (La Sierra del Arzobispo) (1952)

Hermanas Carmelitas de la Caridad:

222. Colegio Santa Teresita (Varadero) (1954)

223. Colegio Sagrado Corazón (Varadero) (1957)

Religiosas de los Santos Angeles Custodios:

224. Colegio de los Santos Angeles Custodios (Media Luna) (1955)

225. Colegio Santa Lucia (1957)

Misioneros de los Sagrados Corazones de Jesús y de María:

226. Colegio Sagrado Corazón de Jesús (Sagua) (1957)

(Fernández Soneira 1997, 423-432)

* No specific date offered by Fernández, but is known from interviewees, and research that these schools were founded during the Republic within the indicated decade. 


\section{APPENDIX 2}

Number of Priests in Cuba

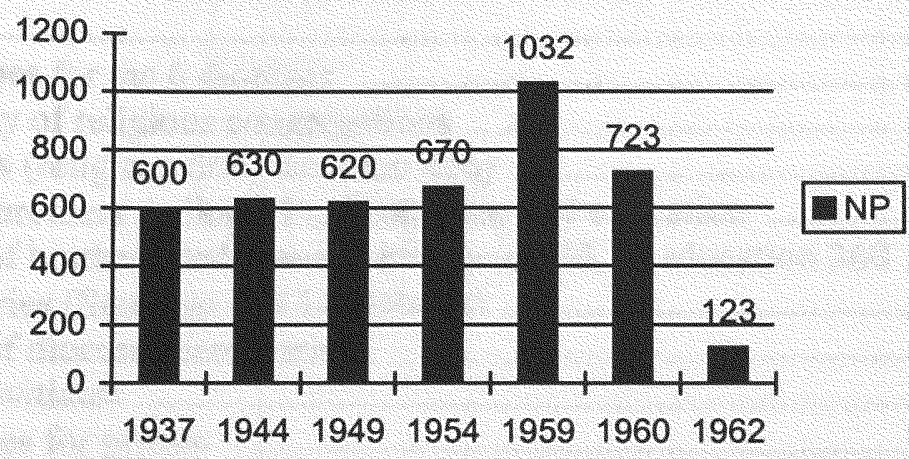

Inhabitants Per Priest

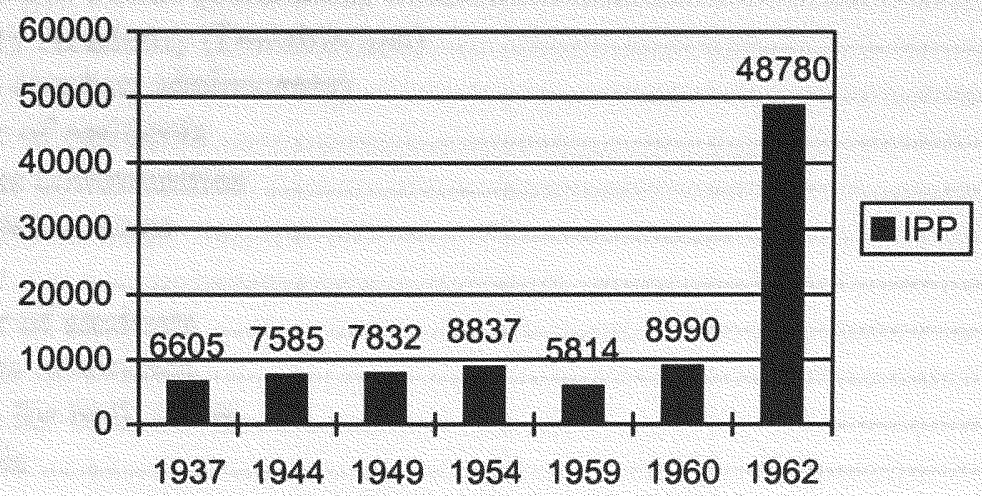

(Turner 1971, 184-185; Testé 1975, 250-251). 


\section{APPENDIX 3}

State of the Catholic Church in Cuba in 1959

Archdioceses (1 archbishop each) ........................................................... 2

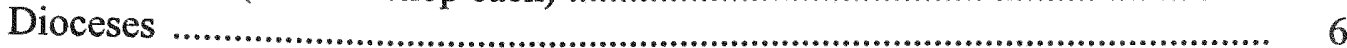

Bishops ......................................................................................................... 8

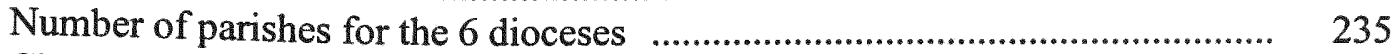

Churches property of religious congregations …….......................................... 23

Number of priests (religious 606, diocesan 426) ............................................. 1.032

Communities of brothers dedicated to healthcare and education ..................... 4

Number of brothers dedicated to healthcare 38, to education $360 \ldots \ldots . . . \quad 398$

Diocesan seminaries (Santiago and La Habana) ................................................. 2

Number of diocesan seminarians ...................................................... 100

Male religious novitiates ................................................................................... 4

Apostolic Institutes for priests ................................................................... 5

Apostolic Colleges ........................................................................................... 55

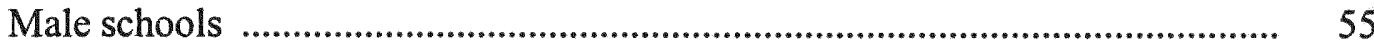

Number of students ............................................................................. 16.000

Universities (La Salle and Sto. Tomás de Villanueva) ...................................... 2

Number of students ............................................................................... 1.600

Electro mechanic school (Jesuits) ............................................................... 1

Number of students .............................................................................. 400

Schools of Arts and Labor (Salesians) ............................................................. 3

Sugar Chemistry Academy (Dominicans) ............................................................ 1

Children Camp (orphan adolescents) .............................................................. 1

Number of residents ........................................................................... 185

Female religious communities ............................................................... 58

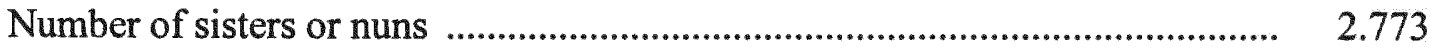

Female schools ....................................................................................... 88

Number of students ..................................................................... $\quad 65.000$

Female religious novitiates ....................................................................... 7

Nursing homes for both sexes .................................................................. 22

Female hospitals .................................................................................................. 3

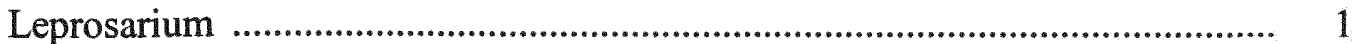

Psychiatry hospitals for both sexes ............................................................... 2

Clinics or sanatoria for females ...................................................................... 1

Clinics or sanatoria for both sexes ............................................................ 1

(Testé 1975, 250-251) 